\title{
Roman Imperialism and the Transformation of Rural Society in a Frontier Province: Diversifying the Narrative
}

\author{
By NICO ROYMANS, TON DERKS and STIJN HEEREN
}

\begin{abstract}
This paper studies rural populations in the Roman frontier province of Germania inferior, employing a perspective that allocates more space to the exploitative and repressive aspects of Roman rule. We draw attention to an alternative series of topics than the ones currently presented in rural archaeology. This includes attention to situations of crisis and instability, to fundamental reordering of rural populations, to issues of migration and to the interconnectivity of rural developments and imperial power structures. While these topics are usually considered as 'historically given', they are rarely the subject of serious archaeological research. This attempt at a more historicising approach does not mean a simple return to the traditional paradigm of historische Altertumskunde. Much better equipped than our predecessors of two or three generations ago, we archaeologists of the 21st century are able to engage in a critical and creative dialogue with historical sources and models.
\end{abstract}

Keywords: Roman imperialism; rural transformations; migration; reordering of populations; historicising approach

\section{INTRODUCTION: THEORETICAL AND METHODOLOGICAL CONSIDERATIONS}

$\mathrm{O}$ ver the course of the past three decades the study of rural populations in the northern provinces of the Roman Empire has experienced a spectacular boost as a result of the upsurge in new excavations generated by the introduction of development-led archaeology. The enormous increase in archaeological data from the 1990s onwards has stimulated new synthesising research on Roman rural settlement and land use. In the Netherlands, research programmes led by the present authors have focused on the study of villa landscapes, the transformation of Batavian society, the integration of peripheral rural communities into the Roman world and the social dynamics on the late Roman frontier. ${ }^{1}$ In

$1 \quad$ Roymans 2004; Roymans and Derks 2011; Roymans et al. 2015; 2017.

(C) The Authors, 2020. Published by Cambridge University Press on behalf of The Society for the Promotion of Roman Studies. This is an Open Access article, distributed under the terms of the Creative Commons Attribution-NonCommercial-ShareAlike licence (http://creativecommons.org/licenses/by-nc-sa/4.0/), which permits non-commercial re-use, distribution, and reproduction in any medium, provided the same Creative Commons licence is included and the original work is properly cited. The written permission of Cambridge University Press must be obtained for commercial re-use. 
Britain, the three-part New Visions of the Countryside of Roman Britain, edited by Michael Fulford and Neil Holbrook, is a major achievement. The volumes on The Rural Settlement of Roman Britain (Smith et al. 2016), The Rural Economy of Roman Britain (Allen et al. 2017) and Life and Death in the Countryside of Roman Britain (Smith et al. 2018) offer excellent regional overviews; they are richly illustrated with high-level quantification and GIS presentations of the primary data. ${ }^{2}$ In France, the recently completed RurLand project directed by Michel Reddé marks a milestone. The edited volumes Gallia Rustica I (2017) and II (2018) present a series of regional and thematic studies covering northern and northeastern France, Belgium, the southern Netherlands and the German Rhineland. ${ }^{3}$ The papers offer a richly documented overview of recent French research.

These and other studies employ different approaches to studying Roman period rural society. By far the most attention is usually directed towards the description and analysis of the primary evidence regarding house architecture, mobile material culture, burial practices, agrarian strategies and regional settlement and land-use patterns. Many studies emphasise the remarkable regional diversity in rural landscapes. This heterogeneity is seen as the result of contingent factors working together, such as the varying natural potentials of landscapes for subsistence strategies, the agency of Roman authorities in the sphere of taxation and exploitation of local resources, and - especially in the cultural sphere - the relative autonomy of individuals and groups in expressing their own identity in the context of the Roman world, thereby creatively appropriating new ideas, lifestyles and material culture. Within this broad spectrum of perspectives Reddé opts for a strongly economic approach, concentrating on the comparative analysis and diachronic development of regional economies and settlement patterns. ${ }^{4}$ In the past two decades, British archaeology - influenced by the post-processual research agenda - has profiled itself with studies on the cultural dimensions of 'becoming Roman' and related identity constructions, thereby often neglecting relations of inequality and interdependency between the agents involved. David Mattingly, however, using a post-colonial approach, emphasises that rural communities should always be studied in relation to hard imperial power structures and that attention should be paid to the varying and often ambivalent attitudes of individuals and groups towards Rome. ${ }^{5}$

In this contribution we would like - much in line with Mattingly - to argue for a perspective on rural societies that allocates more space to the exploitative and repressive aspects of Roman rule. Particularly in the domain of rural archaeology, this perspective is often underdeveloped. Dominant in Roman rural archaeology is the narrative of 'romanisation' that often implicitly reproduces a classical humanistic ideal of civilisation. Even though rural groups may have lived far removed from the urban and military centres, we should realise that they were not situated in a power vacuum. Their functioning and identity constructions should always be understood in their relation to imperial power networks. This is a line of research that is deeply rooted in Dutch research traditions, strongly determined by the geographic situation of the Netherlands in the Germanic frontier zone of the Roman Empire. ${ }^{6}$ From this frontier perspective we draw attention to an alternative series of 'big issues' with the aim of producing narratives other than those currently presented in rural archaeology. While these topics are usually considered as 'historically given', they have rarely been the subject of serious archaeological research. The perspective employed here is distinguished by its explicit attention to:

Smith et al. 2016; 2018; Allen et al. 2017.

Reddé 2017; 2018a.

cf. also Reddé $2018 \mathrm{~b}$.

Mattingly 2006, 353-63; Mattingly 2011. On the post-colonial perspective, see also Webster and Cooper 1996; Huskinson 2000; Hingley 2005; Gardner 2013.

6 Bloemers 1978; Willems 1984; Slofstra 2002; Van Driel-Murray 2003; Roymans 2004. On the study of Roman frontiers, see Whittaker 1994; 2009; Breeze 2018. 

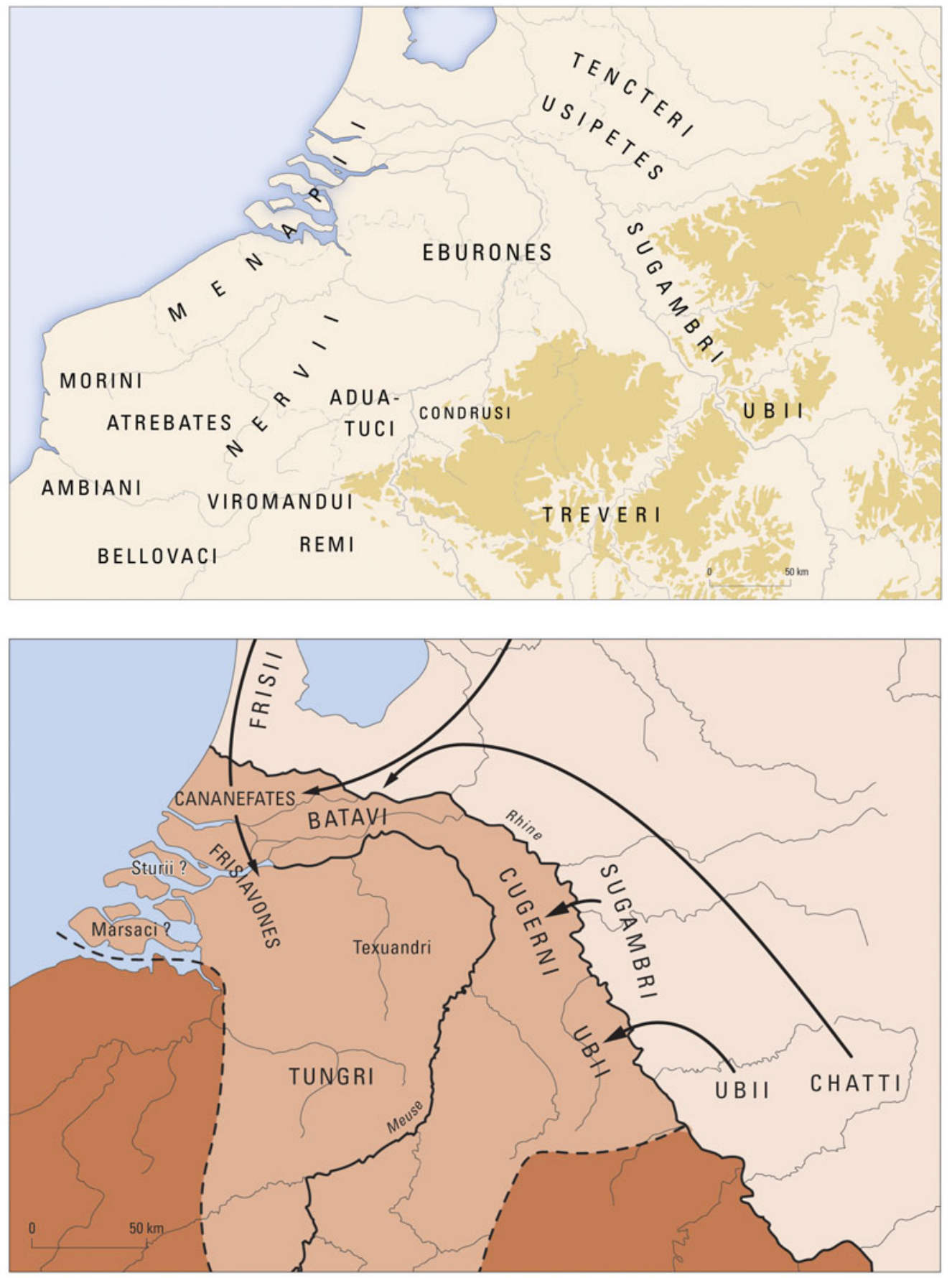

FIG. 1. Tribal map of the Lower Rhine frontier zone in the Caesarian (above) and early Imperial (below) periods. The population movements shown in the latter map are based on written evidence. 
1. phases of fundamental reordering of rural populations;

2. issues of human mobility and migration;

3. understanding rural developments within broader historical contexts;

4. the interconnectivity of rural developments and imperial power structures.

This attempt at a more historicising approach does not mean a simple return to the traditional paradigm of the historische Altertumskunde, where archaeology functioned as a historical sub-discipline. We now have access to an advanced set of social and applied theories, a wide range of methodologies, including new natural-science methods, a hugely augmented archaeological dataset and - last but not least - a much improved chronological resolution of the material evidence. Being much better equipped than our predecessors of two or three generations ago, we archaeologists of the 21 st century are able to engage in a critical and creative dialogue with historical sources and models.

The aim of this paper is to present a regional case study in which we try to operationalise the perspective outlined above. Our study area roughly corresponds to the territory of the military district and later province of Germania inferior (FIGS 1 and 5). Five themes will be discussed in chronological order, all referring to major transformations of rural society and closely related to changing imperial power relations. We are repeatedly confronted with human mobility and migration, the genesis and dissolution of ethnic groups and situations of crisis and instability. We start our discussion of each theme with a brief sketch of the historical framework, after which we see what archaeology can contribute to the debate. We end with some concluding remarks and prospects for further research.

\section{CONQUEST AND THE ARCHAEOLOGY OF MASS VIOLENCE AND GENOCIDE}

In his De Bello Gallico Julius Caesar gives extensive accounts of his military campaigns in the northern frontier zone of Gaul. The tribes living in this zone, called Germani or Germani cisrhenani, faced extreme forms of Roman mass violence and even genocide. Absolute low points were the mass enslavement of the Aduatuci in 57 B.C., the annihilation of the Tencteri and Usipetes in 55 B.C. and the scorched-earth campaigns against the Eburones of 53 and 51 B.C. ${ }^{7}$ However, how seriously can we take Caesar's reports about his use of mass violence? Opinions among modern scholars vary greatly: some consider his descriptions as reflecting a historic reality, while others argue that they are heavily biased by imperialist rhetoric and self-glorification, and that the Roman conquest had relatively little impact on the local population. ${ }^{8}$

A major problem is the archaeological invisibility of Caesar's conquests in the Lower Germanic frontier zone. A mobile army using temporary marching camps and deploying scorched-earth strategies in an attempt to fight decentralised enemy groups leaves very few archaeological traces. However, this situation has changed in the past decade. A battle-related find complex at Kessel near the Meuse/Waal confluence can be interpreted as the probable site where Caesar massacred the Germanic Tencteri and Usipetes. ${ }^{9}$ Given the presence of concentrations of Roman lead sling shot and several gold hoards deposited in the early 50s B.C., a late Iron Age fortification at Thuin in central Belgium may be regarded as the probable oppidum of the Aduatuci, where Caesar enslaved 53,000 people. $^{10}$

Caes., BGall. 2.29-35 (Aduatuci), 4.4-15 (Tencteri and Usipetes), 6.34, 6.44, 8.24-5 (Eburones).

For opposing opinions among German scholars, cf. Galsterer 1990, 117; Eck 2004, 41-2.

Roymans 2018.

10 Roymans and Scheers 2012. Archaeological fieldwork is currently being conducted at Thuin by the Université Libre de Bruxelles with the aim of testing further this hypothesis. 
Furthermore, the archaeology offers the possibility to study the demographic effects of Caesar's conquests. ${ }^{11}$ Starting from the assumption that his campaigns - if taken seriously - must have caused a significant demographic regression in our study area, research has been conducted in five test regions on the degree of settlement discontinuity at the transition from the late Iron Age to the early Roman period. Proceeding from excavated and published settlements, all investigated regions produced evidence for a substantial habitation discontinuity in the course of the first century B.C. (FIG. 2). Although other factors may also have been involved here and a precise dating remains impossible, a connection with the Roman conquest is a very plausible interpretation. ${ }^{12}$

Also relevant is the investigation of the late Iron Age circulation of precious metal in the study area. On the basis of coin-die analyses and cross-datings of recently discovered coin hoards of the so-called Fraire/Amby horizon (FIG. 3), we are obtaining a better picture of the circulation and deposition of high-value coins in the mid-first century B.C. ${ }^{13}$ The 50 s B.C. show a clear peak in coin hoarding, and this picture is reinforced by the many isolated finds of gold coins belonging to this phase, which in many cases will have been deposited as 'mini hoards'. This mid-firstcentury hoarding peak can hardly be interpreted as a temporal upsurge in the accidental loss of precious-metal coins; it must have been crisis related. A link with Caesar's conquest seems plausible. ${ }^{14}$ In particular his campaigns against the Aduatuci and the Eburones will have created large numbers of victims who could no longer recover their emergency concealments of precious-metal coins.

We may conclude that the Lower Germanic frontier zone offers an interesting potential for combined archaeological-historical research on the use of mass violence and genocide in Roman imperial expansion. The 50s B.C. do indeed appear to have been a period of traumatic experiences for the inhabitants of the northern periphery of Gaul. In line with Caesar's reports, large regions seem to have been transformed into landscapes of trauma and terror. The discontinuity in the tribal maps from the Caesarian and early Imperial periods (FIG. 1) also suggests that we should take his reports about depopulation and mass violence seriously.

Finally, the question arises as to how one might explain the excessive Roman violence in this frontier zone. Several factors may have played a role, such as the desire to take revenge for the ambush of a Roman army by the Eburones and the absence of urbanised oppida that would have been easy targets for the Roman army. However, it is also interesting to link the excessive Roman violence to the extremely negative ethnic framing of Germani in Caesar's war account. ${ }^{15}$ They are depicted as barbarians par excellence, as a population of bandits and terrorists who were unsuitable for incorporation into the Empire. ${ }^{16}$ This negative stereotyping of Germani appears as a constant factor in Caesar's narrative from his first war year in Gaul, and it may have influenced his military actions against Germanic groups by removing barriers to the use of extreme violence against them in conflict situations. In BGall. 6.9.7 we read that the Germanic Ubii feared falling victim to 'a general hatred of the Germans' (communi odio Germanorum). This hatred may have reflected the general atmosphere in Caesar's army.

\footnotetext{
11 For the methodology, primary evidence and results of this research, see Roymans 2019.

12 Of course, large-scale settlement discontinuity does not necessarily imply mass violence or massacres, but in combination with historic evidence it may be a serious option.

13 Roymans and Scheers 2012, with interpretations based on the hoards of the so-called Fraire-Amby horizon.

14 cf. also the earlier views expressed in Haselgrove 1984; Nash 1987. For a critical view, see Haselgrove 2019, where it is emphasised that the production of part of Simone Scheers' coinages 'de type belge' had already started before the 50 s B.C.

15 BGall. 4.1-3, 6.21-8. See the discussion in Roymans 2019.

16 cf. Riggsby 2006, 60-1; Schadee 2008; Krebs 2011; 2018, 93-122. On the imaginary geography of Caesar's Germania, see also Krebs 2006.
} 


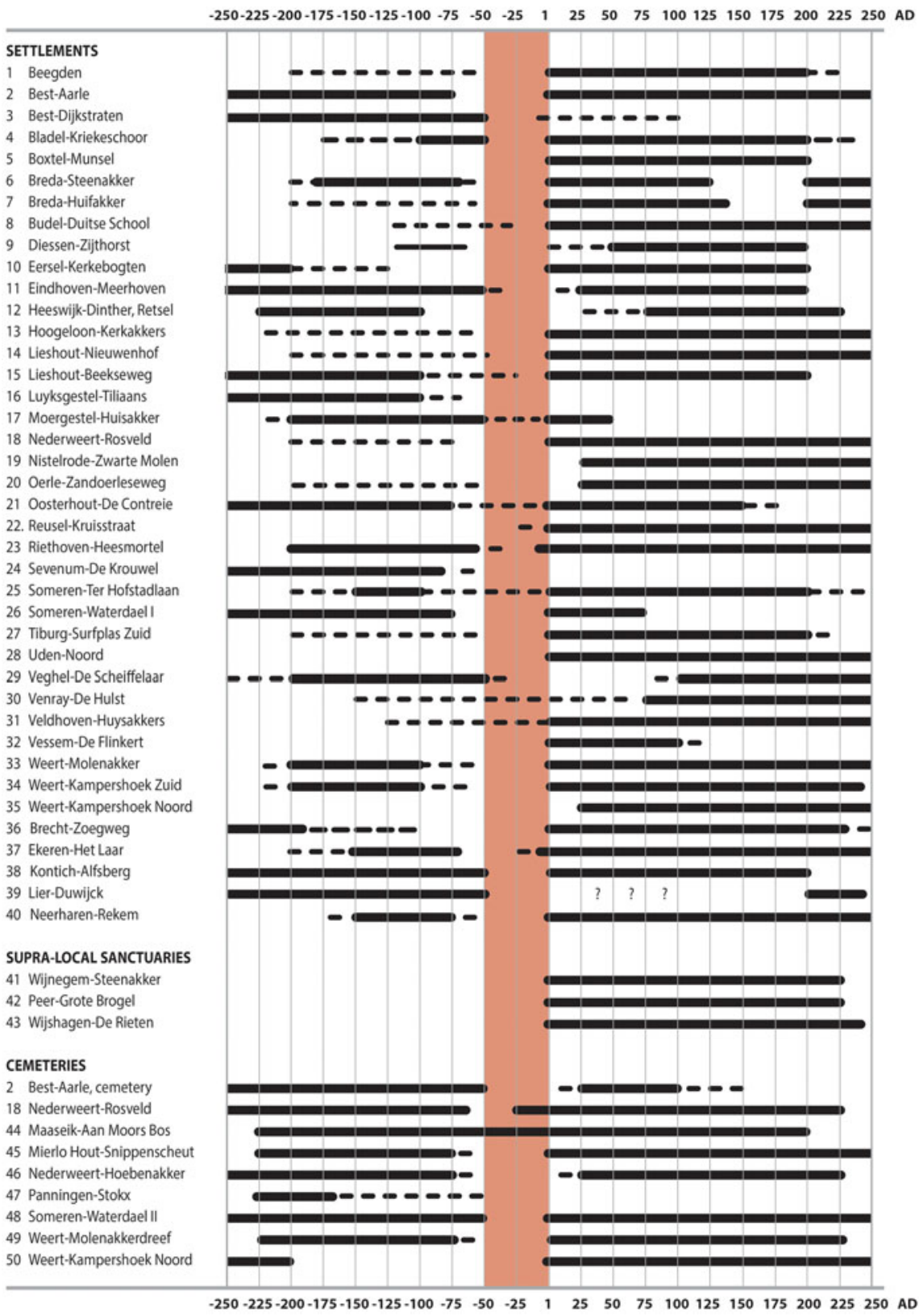

FIG. 2. Diagram of habitation trajectories of excavated rural settlements and cemeteries in the Meuse/Demer/Scheldt area in the late Iron Age and early Roman period, showing a high level of habitation discontinuity in the later first century B.C. and a large-scale recolonisation of the land in the Augustan period (after Roymans 2019, fig. 11). 


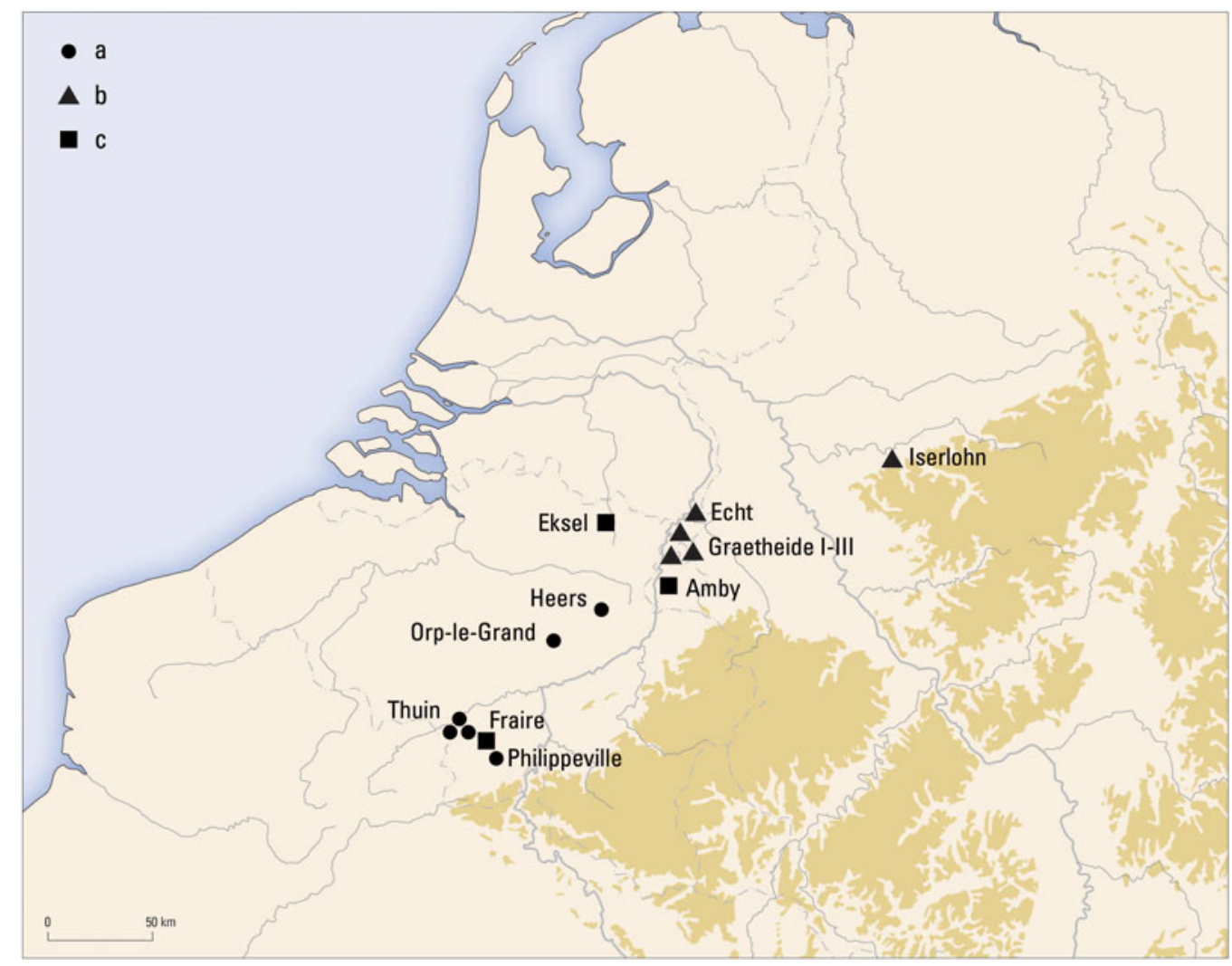

FIG. 3. Distribution of gold hoards of the Fraire-Amby horizon and hoards with silver triquetrum coins from the mid-first century B.C.: (a) hoard with Gallo-Belgic gold staters; (b) hoard with silver rainbow staters; (c) mixed hoard of Rhineland rainbow staters and Gallo-Belgic staters.

Against this background it is perhaps no coincidence that four of the five cases of genocide described in Caesar's war account are clustered in the Germanic north (FIG. 4).

\section{THE AUGUSTAN REARRANGEMENT OF THE LOWER GERMANIC FRONTIER AND THE ARCHAEOLOGY OF MIGRATION AND ETHNOGENESIS}

Based on the written sources, the post-conquest period, and in particular the age of Augustus, can be described as a formative phase for the Lower Germanic frontier zone, characterised by the influx of new Germanic groups from the eastern bank of the Rhine, the formation of new tribes and the first administrative ordering of the military district of Germania inferior. This resulted over the course of the first century in a fundamental reorganisation of the tribal map compared to that of the Caesarian period (FIG. 1). Germania inferior most likely had six civitates (FIG. 5): the Ubii around Cologne, the Cugerni near Xanten, the Tungri with Tongres as their centre, the Batavians around Nijmegen, the Cananefates with their capital at Voorburg and the Frisiavones 


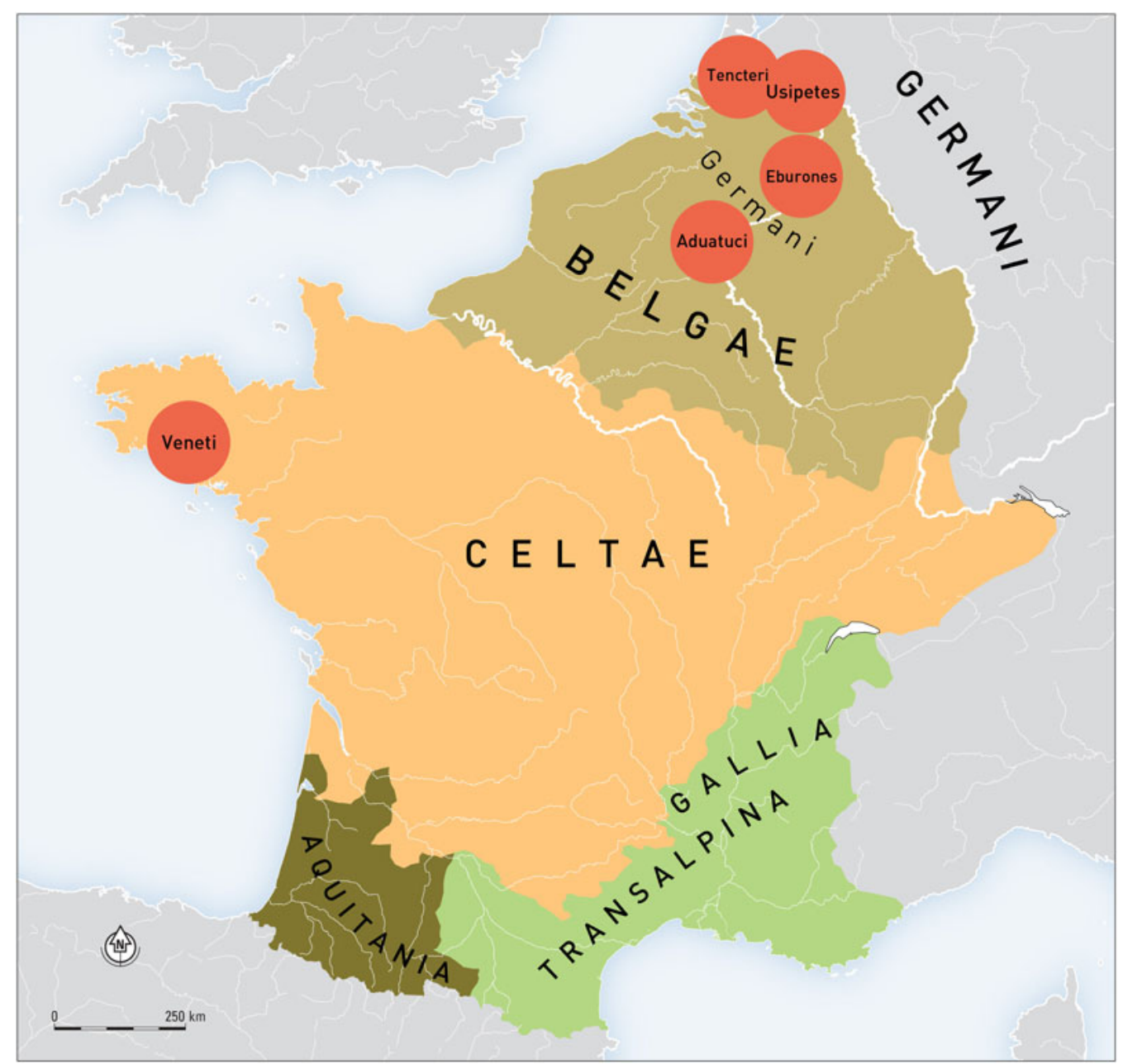

FIG. 4. Gaul at the time of the Roman conquest, with the distribution of the cases of genocide described by Caesar in his Commentarii.

in the coastal area of Zeeland. ${ }^{17}$ In addition, we hear about a number of smaller tribes, such as the Texuandri, Baetasii and Sunuci, which were probably attributed (as pagi?) to one of the civitates mentioned. ${ }^{18}$

In several cases the scarce written sources inform us about the origin of the newcomers (FIG. 1). The Ubii were moved from the right to the left bank of the Rhine (the Cologne region) by Agrippa in $39 / 38$ or $20 / 19$ B.C. ${ }^{19}$ The Batavi - a subgroup of the Chatti who lived in modern Hesse - were allowed to settle in an area said to be empty (vacua cultoribus) in the eastern half of the Dutch Rhine delta at some time between Caesar's departure from Gaul and the arrival of Drusus in

Raepsaet-Charlier 2002-03.

Texuandri: Roymans et al. 2015. Baetasii and Sunuci: Rüger 1968, 97; Bechert 1982, 55-6.

Strabo 4.3.4; cf. Tac., Ann. 12.27; Wolters 2001, 159-60. 


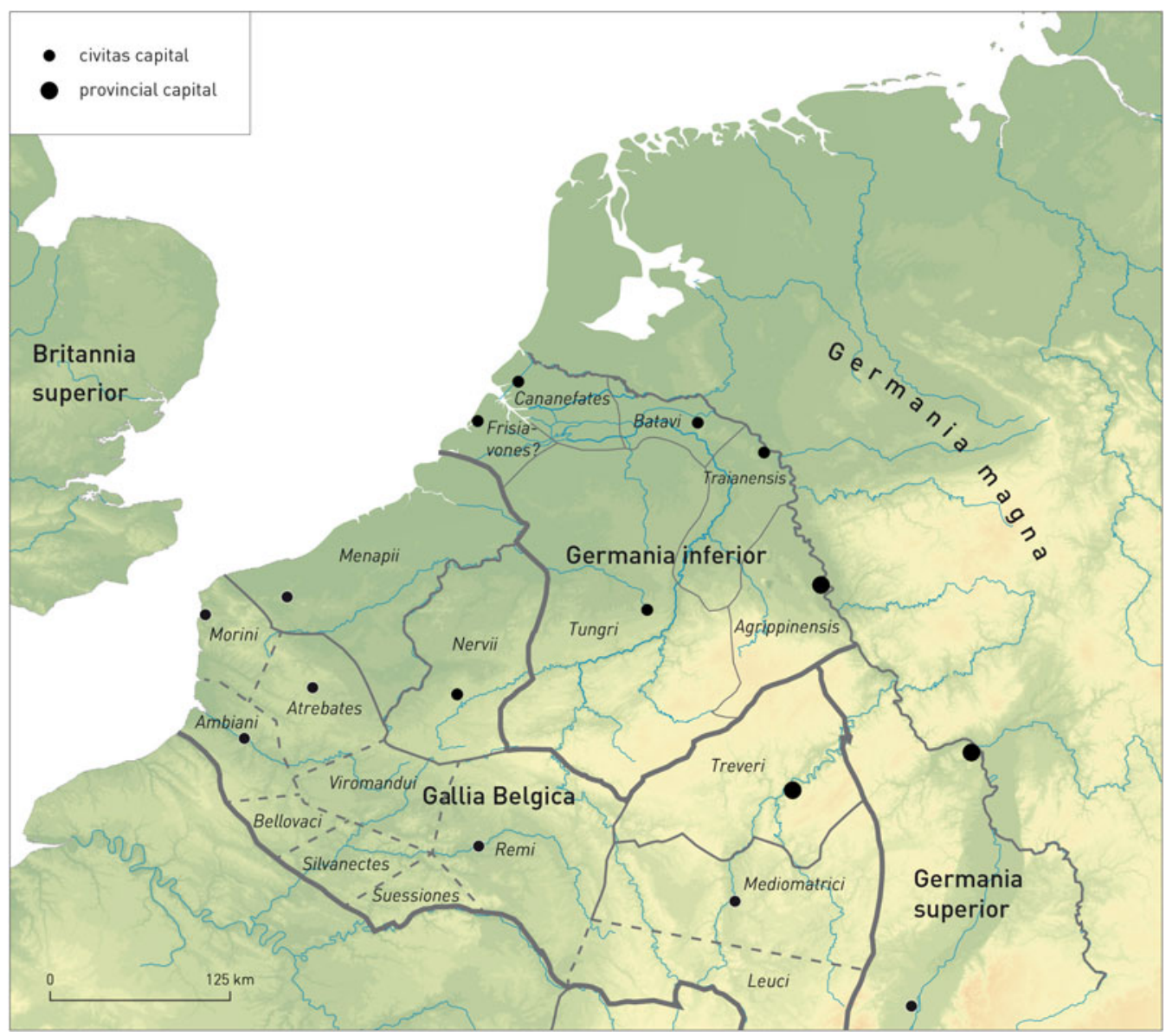

FIG. 5. Germania inferior and neighbouring provinces in the second and early third centuries (after Heeren 2017, fig. 1).

about 15 B.C. ${ }^{20}$ In 8 B.C. Tiberius transferred a group of 40,000 subject Sugambri and Suebi to the Gallic bank of the Rhine, where they were probably settled in sparsely populated regions; this is the only case for which we have information about the size of an immigrant population. ${ }^{21}$ The Cugerni and the Baetasii in the Xanten territory are often regarded as potential descendants of this immigrant group. ${ }^{22}$ The Cananefates in the Dutch coastal area had a close relationship with the Chauci, and probably originated in the North Sea coastal area, ${ }^{23}$ and the Frisiavones are often considered the descendants of a group of Frisians transferred by the Roman general Corbulo in $47 .{ }^{24}$ Although this is not always explicitly mentioned, it is clear that the land

20 Tac., Germ. 29.1; Hist. 4.12; Roymans 2004, 55-65.

21 Suet., Aug. 21; Tib. 9; Tac., Ann. 12.39; Wolters 2001, 163-7.

22 Rüger 1968, 96-8; Bechert 1982, 55-6; Heinrichs 2001. The Texuandri in the Meuse/Demer/Scheldt region are also potential descendants of the Sugambri.

23 Tac., Ann. 11.18; De Bruin 2019, 7, 149-56.

24 Tac., Ann. 11.19; Raepsaet-Charlier 2002-03, 44; De Bruin 2019, 150. 
allocations to Germanic groups were often directed or at least sanctioned by the Roman authorities, thereby continuing a long tradition of rearranging both land and people in newly conquered areas. ${ }^{25}$

This settlement of new Germanic groups on the Gallic bank of the Lower Rhine meant a fundamental change in Roman frontier policy from Caesar's anti-Germanic policy based on exclusion and negative ethnic framing. Under Augustus, Rome switched to a strategy of incorporating Germanic groups on the right bank of the Rhine and transferring groups to the heavily depopulated Gallic bank of the river. An important motif for this change of policy is the repopulation of sparsely inhabited land and no doubt the exploitation of the military potential of Germanic groups; from the Augustan period onwards groups in Germania inferior were recruited on a massive scale for the military (see below).

What can archaeology add to the historical picture summarised above? While it is clear that these changes must have had a profound impact on the rural populations that had been living there, in archaeological terms almost no questions relating to this dynamic period have been asked so far. To what extent can we see this influx of Germanic groups archaeologically? How should we envisage this process of ethnogenesis of new groups? And what was the role of the Roman authorities in all this? It is only recently that archaeology has become equipped with the right methodological tools to study the theme of migration in the Lower Rhine frontier zone. Over the past two decades significant progress has been made by viewing the new Germanic frontier tribes first and foremost as political constructs arising from fusions of autochthonous and immigrant groups under the direction of the Roman military authorities. ${ }^{26}$

The archaeology of rural settlements can contribute to this debate by testing and improving the essentially historic migration models. Important tools in this context are conventional materialculture studies of personal ornaments, handmade pottery and indigenous house architecture, in combination with strontium isotope studies of dental remains of domestic animals and chemical analyses of pottery and metal ornaments. A specific pilot study is currently running in the Batavian river area, ${ }^{27}$ where we are trying to identify first-generation farmsteads of newly founded rural settlements, thereby using the methods listed above to trace the geographic origins of the settlers. The first results are promising and suggest that the influx of Germanic groups was more diverse than the scarce written sources suggest. In the Batavian area, we encounter a mixture of material culture of local origin, but also from the Rhine/Weser area and the North Sea coastal region. On the basis of pottery style and house architecture, Jasper De Bruin presumes that the settlers in the territory of the Cananefates originated from the North Sea coastal area. German archaeologists point to the occurrence of 'Elb-Germanic' domestic pottery in rural settlements on the west bank of the Rhine in Ubian territory. ${ }^{28}$ The most plausible ethnogenetic model for the frontier tribes noted above is that they developed out of a fusion of several immigrant groups of heterogeneous origin, possibly spread over time, that were permitted or simply forced by the Roman military to settle down in exchange for supplying auxiliaries. Larger incoming groups may have been granted the status of civitas,

25 cf. De Blois 2017; Woolf 2017. An interesting parallel for a forced deportation of a defeated people by Rome is Livy's account (40.38.2-3) of the fate of the Ligures in 180 B.C.: 'The Liguri made frequent entreaties through ambassadors that they might not be compelled to leave their household gods, the land in which they had been born, the tombs of their ancestors, and also promised arms and hostages. When they met with no success and lacked the strength to fight, they obeyed the edict.' The Liguri, about 40,000 free men with their wives and children, were resettled on Roman state land, and both Roman consuls were awarded a triumph for their successful campaign.

26 cf. Roymans 2004 (Batavians); Raepsaet 2013 (Tungri); De Bruin 2019 (Cananefates).

27 Tiel-Medel as a Key Site for Innovative Research Towards Migration and Ethnogenesis in the Roman Frontier (see Acknowledgements). On the methodology of migration studies of the Roman Empire, see Eckardt and Müldner 2016.

28 Andrikopoulou-Strack et al. 1999, 149-55; Hornung 2016, 297-302; Frank 2018; De Bruin 2019. 
while smaller groups were usually allocated to an already existing civitas, where they may have retained some degree of autonomy. The core of the immigrant groups usually consisted of a war band that was obliged to offer its service to Rome.

We may conclude that the Augustan period was a phase of repopulation of the land and of the formation of new ethnic groups that should be seen as political constructs which mask a much more heterogeneous ethnic reality. The new ordering was to a large extent the product of Roman frontier policy aimed at the large-scale exploitation of Germani as ethnic soldiers. Archaeology can contribute to the discussion by testing and improving the current historical models with regard to the migration and ethnogenesis of groups in the Lower Rhine frontier.

\section{A BREEDING GROUND FOR SOLDIERS: THE IMPACT OF LARGE-SCALE AUXILIARY RECRUITMENT}

A specific characteristic of the Lower Germanic region compared to many other frontier areas of the Roman Empire was the high level of ethnic recruitment for the Roman army among indigenous rural groups (FIG. 6). This practice of ethnic soldiering was already in full swing in the Augustan-Tiberian period and developed further over the course of the first century, when the initially irregular war bands were transformed into regular formations of full-time soldiers. The impressive list of pre-Flavian ethnic units suggests that the military government obliged each tribe to supply a specific number of auxiliary units. This practice of ethnic recruitment created a close relationship between native rural groups and the Roman military community. It confronts us with a specific form of human mobility, one which primarily involved individuals who served in the army for a long period and some of whom returned later as veterans. This latter practice in particular had an enormous social impact in the first century since it brought inhabitants from almost every settlement within a civitas into contact with the military variant of Roman culture.

This interaction between the rural and the military communities has been intensively explored in Dutch archaeological research of the last two decades, which has relied heavily on the systematic registration and analysis of metal-detection finds from private and public collections. ${ }^{29}$ Roman militaria are frequently encountered in rural contexts. For the Batavian region a model has been proposed of the agency of returning auxiliary veterans in the spread of the Latin language and script, including long-distance communication between soldiers and their homeland, based on certain texts from the Vindolanda archive. ${ }^{30}$ The close link with the military domain brought about a rapid spread of Roman citizenship among the rural community and the formation of military families that supplied soldiers generation after generation. Certainly for the pre-Flavian period, it can be assumed that Roman pottery, coins, fibulae and other ornaments mainly entered native settlements via military networks. ${ }^{31}$ The intensive appropriation of Roman mobile material culture went hand in hand with a conservative adherence to the native byre-house traditions and burial practices. Wouter Vos links the addition of a wooden portico to some indigenous farmhouses with the impact of veterans, who were inspired by the military architecture of army camp barracks. ${ }^{32}$ An indirect indication of the crucial role of ethnic soldiering in Germania inferior, and in particular among the Batavians, is the popularity of the martial Hercules cult in this region. ${ }^{33}$

29 Nicolay 2007; Roymans 2011.

30 cf. Bowman and Thomas 1994-2003, 2.310, 2.346. Derks and Roymans (2002) interpret bronze seal-boxes from rural settlements in the Rhine delta as indirect evidence for Latin literacy. Colin Andrews (2013) proposes an alternative interpretation of the boxes as objects used for sealing packages of money. It is difficult to believe, however, that this was the only way seal-boxes were used.

31 Roymans 2011; Roymans and Derks 2015.

32 Vos 2009, 237-51.

33 Roymans 2009. 

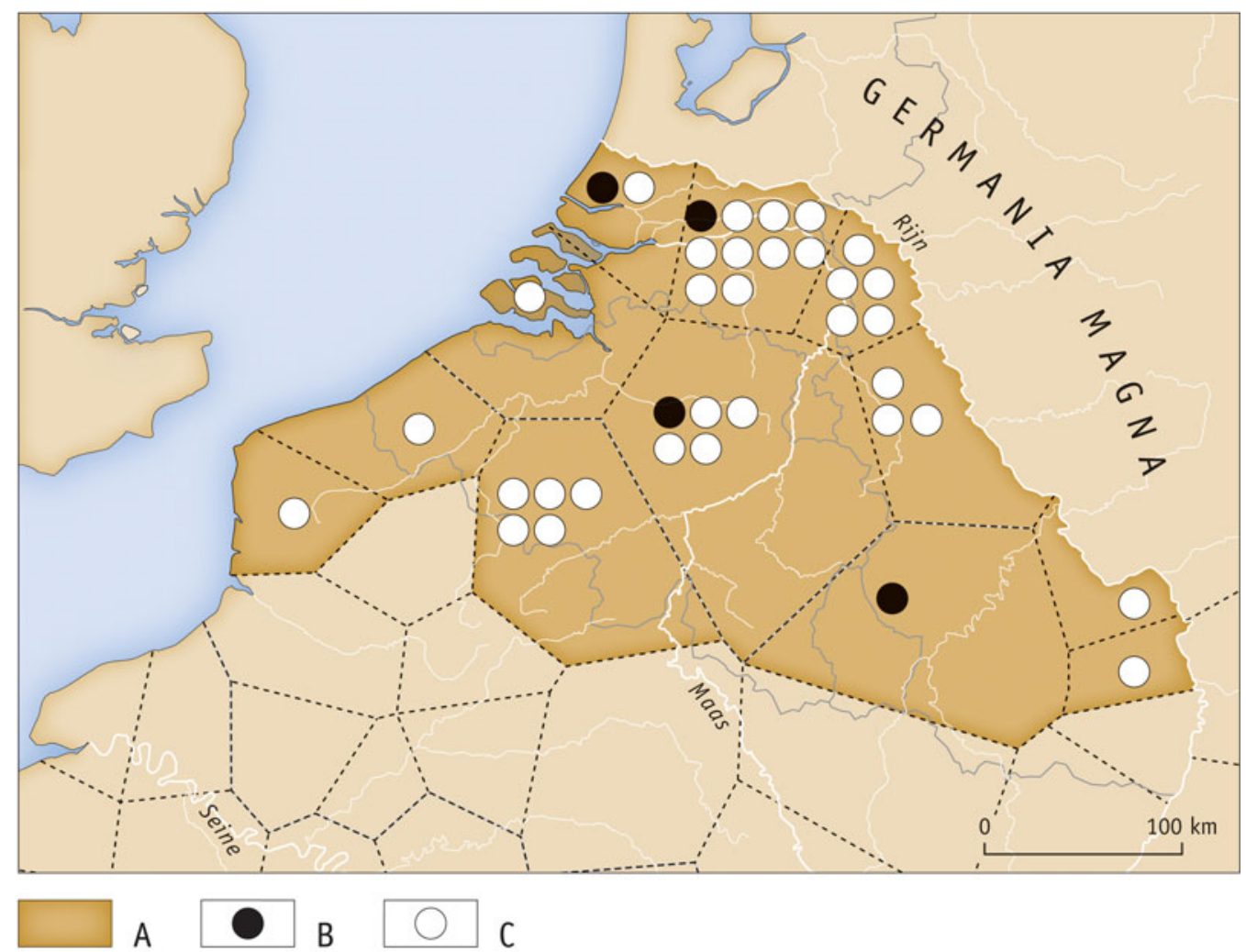

FIG. 6. Overview of pre-Flavian ethnic recruitment by Rome in Germania inferior and Gallia Belgica (data after Alföldy 1968): (A) civitates used for the conscription of auxiliary units; (B) ala; (C) cohors.

This Batavian model cannot simply be extrapolated to the entire region of Germania inferior. Nonetheless, almost all communities in the pre-Flavian period seem to have played a role as providers of auxiliary units. The Batavians continued to cultivate their identity as a soldiering people the longest; up into the third century, Batavian soldiers fostered their collective identity in grave and votive inscriptions, in particular by using the tribal affiliation natione Batavus, 'born a Batavian'. ${ }^{34}$ In other districts this military tradition was abandoned much earlier, especially in the emerging villa landscapes. Ethnic recruitment was most deeply rooted in the poorer rural regions where there was an emphasis on animal husbandry. Military service certainly offered opportunities to individuals as a source of income and a chance to acquire citizenship and a legal marriage. However, the constant recruitment pressure will also have raised tensions and given cause for excesses, as described by Tacitus in his account of the start of the Batavian Revolt. ${ }^{35}$

We see a different development in the civitates of the Ubii and the Cugerni, where coloniae were founded in the towns of Cologne and Xanten, under the reign of Claudius and Trajan respectively. ${ }^{36}$ The founding of colonies implies the settlement of a group of legionary

34 Roymans 2004, 253-8; Derks 2009.

35 Tac., Hist. 4.14.

36 Cologne: Eck 2004, 127-61; Lenz 2006. Xanten: Eck 2008. 
veterans, which often meant a serious infringement on local landownership and power relations. It is not clear, however, to what extent these veterans also settled in the countryside and acquired land at the expense of the indigenous community. In the Cologne hinterland around Jülich there is evidence for a systematic colonisation of previously uninhabited land in the Claudian period. ${ }^{37}$ The new settlers may have been retired legionaries or colonists from interior Gaul but - given the layout of the farmsteads and the architecture of the earliest houses ${ }^{38}-$ they were not of local Germanic origin.

We may conclude that archaeology can contribute to the debate outlined above by enabling study of the impact of ethnic recruitment, veteran behaviour and, more generally, the military variant of Roman culture on rural communities. From a theoretical point of view it is interesting that this impact occurred not only via a top-down élite model, but above all through the agency of common soldiers. Finally, it is remarkable to observe that the short intermezzo of the Batavian Revolt of A.D. 69-70 appears to be almost untraceable in the rural archaeological record; there are no indications of a break in the use of settlements and cemeteries, nor of a demographic decline. The revolt certainly did not lead to a fundamental reordering of rural habitation comparable to those attested there in other periods.

\section{THE LATE THIRD-CENTURY CRISIS AND THE DEPOPULATION OF THE COUNTRYSIDE}

For the later third century we are again confronted with a dramatic rural transformation in our study area. According to the written sources, several interrelated political-military factors were at play. ${ }^{39}$ Wars on the frontiers of the eastern provinces as well as internal strife led to the displacement of troops from the northern borders, which directly triggered Germanic invasions. Many short-lived emperors and usurpers claimed the throne and lost their lives, often at the hands of Roman rivals but some by 'barbarian' armies. These upheavals were followed by regional secessions, such as, in our area, the Gallic Empire (A.D. 259-74) founded by Postumus. There are hints in the written sources that Postumus employed a double strategy with regard to the Germanic threat: he fought them using military means, but also concluded alliances and settled them within the province in order to include barbarians in his army. ${ }^{40}$

What can archaeology contribute to this discussion? The key issue by which rural archaeology can distinguish itself is the study of the depopulation of the countryside. The phenomenon of massive depopulation has been a long-held assumption, but is becoming more and more an empirical reality. Large numbers of excavated settlements form the empirical basis for this research. In all areas of Germania inferior we observe settlements coming to an end, although the intensity of this varies regionally (FIG. 7). In the Pleistocene sandy landscapes of northern Belgium and the southern Netherlands (MDS region), as well as the coastal area of the Cananefates, the depopulation seems to have been almost complete (FIG. 8). ${ }^{41}$ Here we observe the large-scale abandonment of indigenous settlements in the second half of the third century, and evidence of habitation in the early and middle part of the fourth century is very scarce. ${ }^{42}$ In the Batavian and Traianensian area, more single finds of coins and crossbow brooches from

\footnotetext{
37 Lenz 2006; Gaitzsch 2011.

38 Heimberg 2002-03, 68-70.

39 Drinkwater 2008, 30-50.

40 De Boone 1954, 29-35, in detail; Todd 2008, 444, more broadly.

41 MDS region: Heeren 2015; 2017. Cananefatian region: De Bruin 2019, 213-19. See also Van Enckevort et al. 2017.

42 This contrasts with sites north of the Rhine, where dendrochronology has identified early and mid-fourth-century activity and where plentiful house plans and mobilia have been found. Cf. Van Es 1967; Taayke et al. 2012. Dendrochronology: Erdrich 1998 cites several examples.
} 


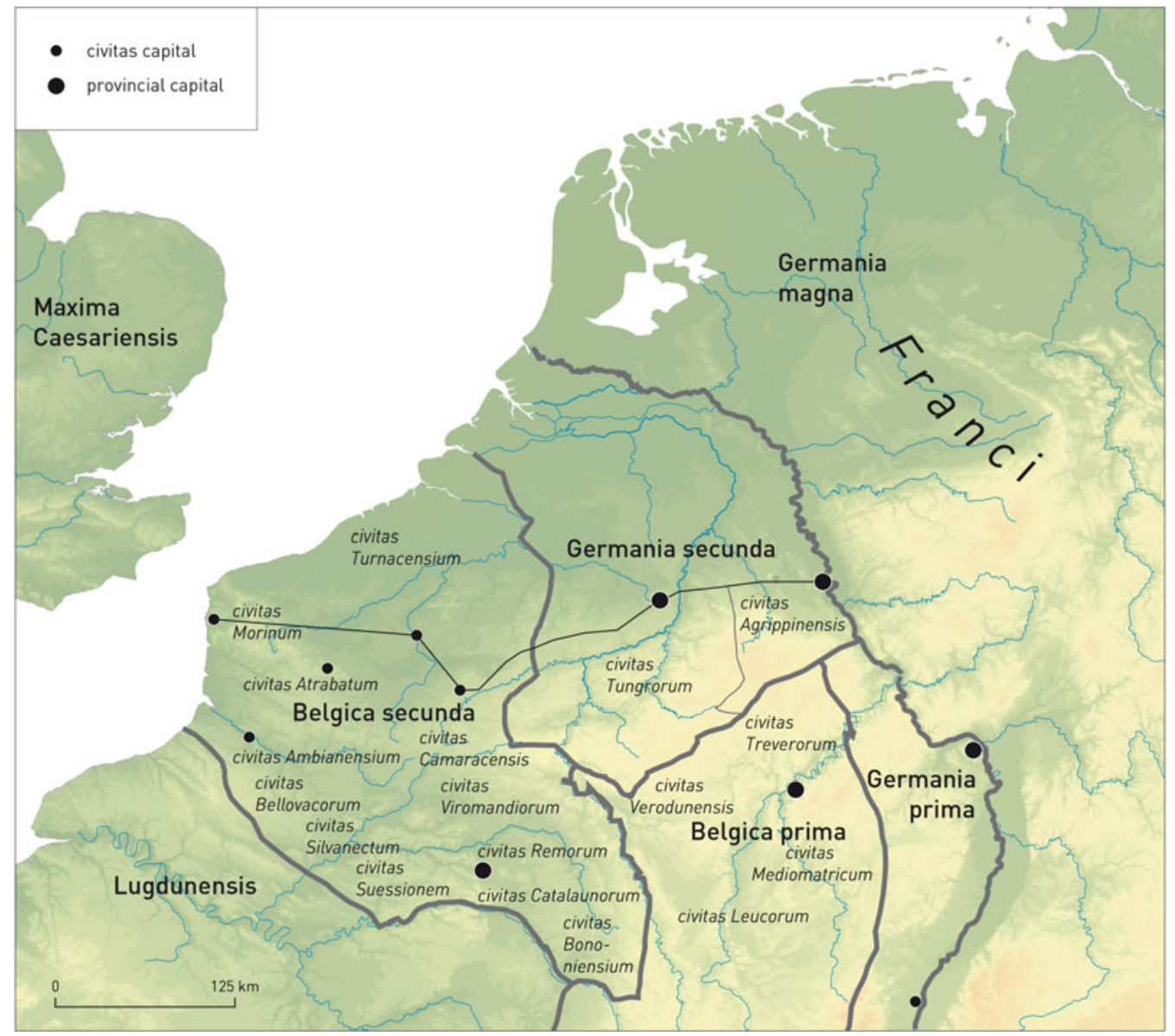

FIG. 7. Germania secunda and neighbouring provinces in the early fourth century (after Heeren 2017, fig. 3).

rural sites hint at some habitation in the fourth century. However, in this region too, almost all excavated settlements and cemeteries were abandoned in the late third century. ${ }^{43}$

Rural depopulation as described for the northern regions, which were essentially non-villa landscapes, was less complete for the more southern villa landscapes in the Cologne hinterland and the Belgian loess region around Tongres. Several survey studies are available for the Cologne hinterland. An older but still useful study is that by Michael Gechter and Jürgen Kunow, ${ }^{44}$ who used pottery from fieldwalking campaigns and excavations as a proxy of the habitation history of several subregions. Regions north of the road from Tongres to Cologne show decreasing site numbers from the second to the third century and a complete absence of sites in the fourth century. Regions south of the road show survival rates (the number of fourth-century villas compared to early third-century ones) of 71 per cent, 52 per cent and 30

43 Xanten area: Brüggler et al. 2017, 30. Batavian region: Willems 1984, 142-61; Heeren 2009, 201-13; Vos 2009, 216.

44 Gechter and Kunow 1986. 
$\begin{array}{lllllllllllllll}125 & 150 & 175 & 200 & 225 & 250 & 275 & 300 & 325 & 350 & 375 & 400 & 425 & 450 & 475\end{array}$

Grobbendonk-Steenbergen

Kontich-Kazernen

Halder (St. Michielsgestel)

Antwerpen-Mortsel

Hoogeloon-Kerkakkers

Neerharen-Rekem

Alphen (NB)-De Bartjes

Alphen-Kerkakkers

Brecht-Zoegweg

Breda West-Huifakker

Breda West-Steenakker

Boxtel

Cuijk-Heeswijkse Kampen

Cuijk-De Nielt

Deurne-Gr. Bottelsche Akker

Duizel-De Heidalen

Eersel-Kerkebogten

Ekeren

Geldrop-'t Zand

Goirle-Huzarenwei

Helden-Schrames

Helmond-Brandevoort

Herk de Stad-Donk

Hilvarenbeek-Zijthorst

Horst-Hoogveld Oost

Lieshout-Beekseweg Oost

Lieshout-Beekseweg Mid/West

Lieshout-Nieuwenhof

Meldert-Zelemsebaan

Nederweert-Rosveld

Oelegem

Oosterhout (NB)

Oss-Eikenboomgaard

Oss-IJsselstraat

Oss-Vijver

Oss-Westerveld

Oss-Zomerhof

Reusel-Kruisstraat

Riethoven-Heesmortel

Someren-Ter Hofstadlaan

Someren-Steemarksweg

Someren-SRV-terrein

Son en Breugel-Ekkersrijt

Turnhout-Tijl en Nelestraat

Valkenswaard-Zeelbergse Akkers

Veldhoven-Zilverackers

Venlo-Blerick-Heierhoeve

Venray-Hoogriebroek

Weert-Kampershoek

Weert-Molenakker

Wijshagen-De Rieten

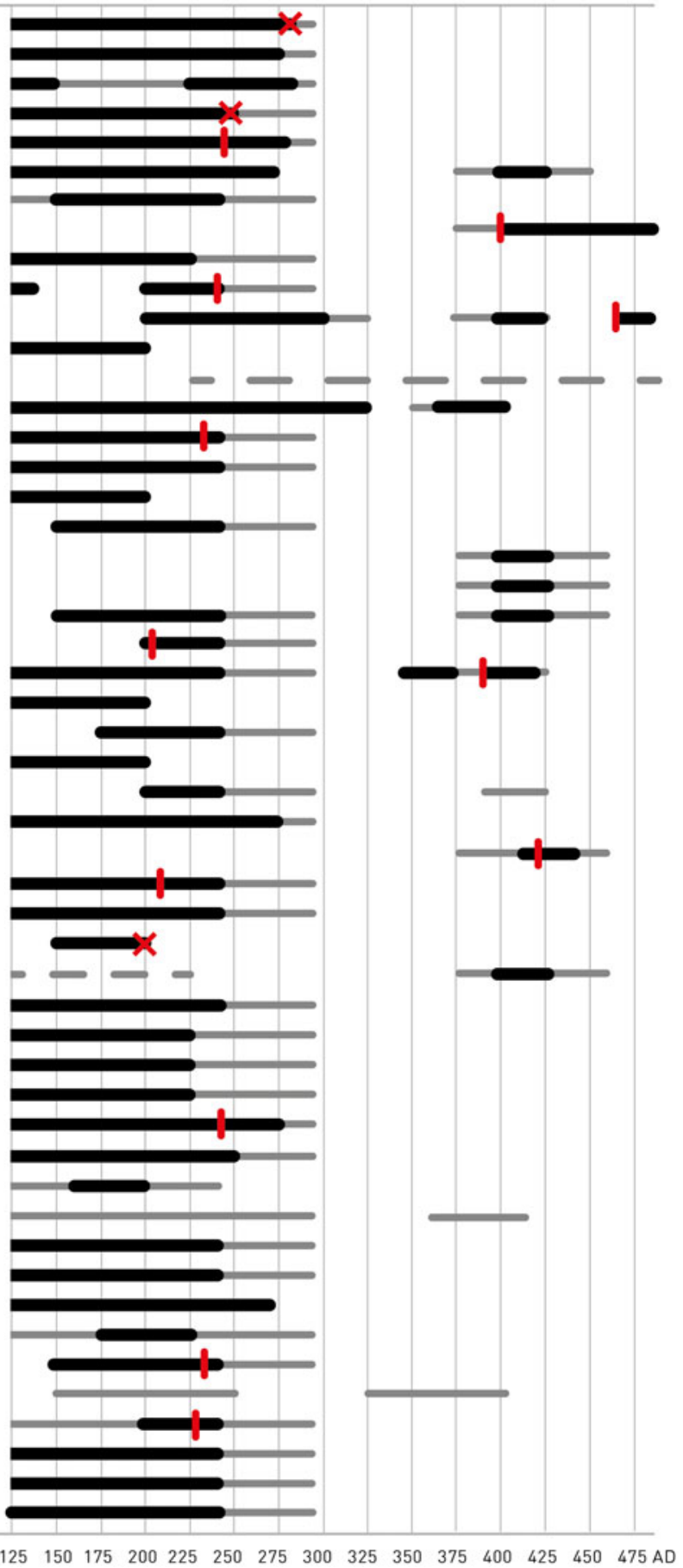

FIG. 8. Diagram of habitation trajectories of excavated rural settlements in the Meuse/Demer/Scheldt region in the later Roman period, showing an almost complete depopulation in the later third century and partial resettlement in the late fourth/early fifth century (after Heeren 2015, table 5, with additions). Thick horizontal line: habitation period with good evidence; thin horizontal line: dating evidence uncertain; red cross: supposed fire catastrophe; vertical red line: dendrochronological date of well. 
per cent. For the Aldenhovener Platte, Karl-Heinz Lenz argues that the decline had already begun in about the middle of the third century. The number of early fourth-century villas is almost half that of early third-century sites. ${ }^{45}$ This is confirmed by the evidence from excavated settlements, showing that many of the villa sites in the Cologne hinterland were abandoned by the late third century. ${ }^{46}$ The same is true for the Nervian countryside, where there is even evidence for a 'desertification' of certain subregions. ${ }^{47}$

The archaeological evidence for depopulation is further substantiated by palynological research. Pollen diagrams from the hinterland of Cologne and the river area in the north show a substantial increase in tree pollen and a decrease in settlement indicators from the second half of the third century onwards, suggesting that many settlements were abandoned and that much of the land was waste ground. ${ }^{48}$ The pollen diagram from Kleefsche Beek in the hinterland of Xanten shows a drastic decline in settlement-indicating pollen from the second half of the third century, implying a return to a forest landscape at a level not reached since Neolithic times. ${ }^{49}$

The depopulation of the countryside sketched above was not an isolated phenomenon but was paralleled by a serious urban decline and in some cases even collapse. Several civitas capitals north of the Bavai-Cologne line seem to have been given up. The civilian centres of Voorburg/Forum Hadriani and Nijmegen/Ulpia Noviomagus were abandoned more or less completely in the late third century. ${ }^{50}$ The new fortification erected at Nijmegen-Valkhof can best be interpreted as a military site, an interpretation that is strengthened by the recently proposed identification of this site as Castra Herculis, one of the military sites rebuilt by Julian II in $358 .{ }^{51}$ At Xanten a new defensive circuit was set around a much reduced core. Since Xanten was probably now called Tricensimae, a reference to the Legion XXX, and the surrounding countryside appears to have been largely uninhabited, it seems likely that Xanten had lost its function as a civitas capital and now primarily served as a military base. ${ }^{52}$ Tongres and Cologne seem to be the only civitas capitals of Germania inferior that survived the late third-century crisis, albeit on a much reduced scale. ${ }^{53}$

We can seriously question whether the administrative infrastructure of the northern civitates survived the end of the third century if there were no civil centres and hardly any rural settlements. The indirect consequences must have been dramatic, ranging from a substantial loss of the provincial tax revenues to the dissolution of the traditional ethnic identity groups which had their basis in the countryside. The collapse of the four northern civitates and the survival of Tongres and Cologne corresponds well to the situation described in the Notitia Galliarum, an appendix to the Notitia Dignitatum. ${ }^{54}$ This document was compiled in about 423 but is often assumed to represent a fourth-century situation in most cases. ${ }^{55}$ The Notitia Galliarum states that Germania secunda had only two civitates: the Agrippinensian metropolis and the Tungrian civitas. ${ }^{56}$

Archaeologists have been debating the causes of the depopulations in Germania inferior. It is clear that we are dealing here with a complex combination of supra-regional, long-term

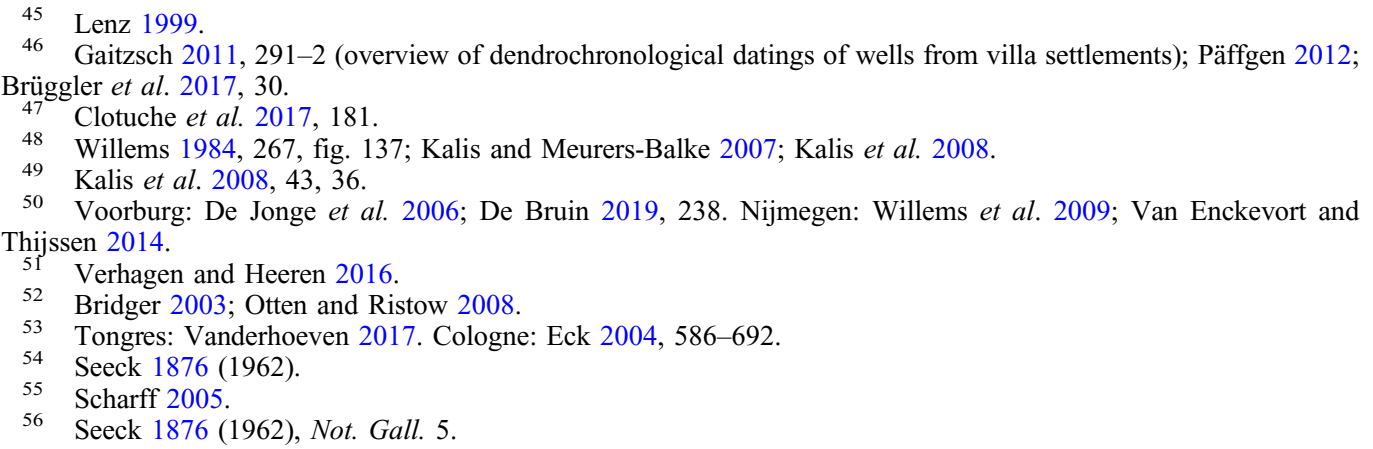


economic and environmental factors, and factors working at a more regional level. The civil wars between Roman contenders, as well as the various barbarian incursions mentioned in the written sources, are obvious candidates, but the Plague of Cyprian dated to the 250s could also have played a role. Modern authors have proposed climate change with colder summer temperatures in the northwestern provinces from A.D. 250 onwards, resulting in rising groundwater tables and partial flooding of coastal wetlands. ${ }^{57}$ Large-scale soil degradation may also have been a significant factor. ${ }^{58}$ Rural settlement research in the southern Netherlands and northern Belgium has provided hardly any evidence of the burning down of the youngest farmsteads. If that were the case, the deepened byre sections present in most farmhouses of this period would have preserved remains of burnt layers, but this is attested only three times (see FIG. 8). What might help to solve this question in the future is a narrower dating of the depopulation. For the moment we must be content with assuming a combination of long-term phenomena, such as a slow soil degradation and climate change, and incidental factors such as warfare, as being responsible for the rural depopulations.

The explanations mentioned above may indeed have caused a serious population decline, but they cannot account for the relatively swift and near total depopulation of regions. In this context it is important also to consider the role of imperial power as an active agent in the process of massive depopulation, thereby referring to evidence for forced deportation of groups. ${ }^{59}$ With regard to the episode of the Gallic Empire and its aftermath, some clues can be found in the written sources. Postumus, the founder of the Gallic Empire, is said to have employed troops of Germanic descent in his war against Gallienus, which is supported by the distribution of gold coins of Postumus in Germania magna. ${ }^{60}$ Aurelian ended the Gallic secession and brought the territories back under Roman rule (274), but his murder led to further chaos. Two passages from a few years later point to the forced deportation of people from the northern civitates. In the first, Maximian Augustus (286-305) is said to have settled Franks in Nervian and Treveran wastelands, 'by which they regained their old position and were part of the law again', thereby suggesting that these Franks had inhabited Roman land earlier, no doubt in Germania inferior. ${ }^{61}$ In the second, Constantius Chlorus is said to have defeated, in around A.D. 293 or 297, a Frankish group that had settled earlier in Batavia, where they had been commanded by a former native of the place, probably of Roman provincial origin. ${ }^{62}$ Constantius deported the defeated Franks to interior Gaul, forcing them 'to lay aside their weapons and fierceness'. Although some translators postulate this leader to be Carausius the Menapian, ${ }^{63}$ both Willem Jan De Boone and Willem Willems strongly argue that he should be identified as Postumus. ${ }^{64}$

\footnotetext{
57 Climate change: Haas 2006; McCormick et al. 2012; Gouw-Bouman et al. 2019, who reconstruct a drop in summer temperature of 1.5 degrees from A.D. 250 onwards; Riechelmann and Gouw-Bouman 2019. Flooding of Dutch coastal wetlands: De Bruin 2019, 218-19.

58 Groenman-Van Waateringe 1983.

59 Heeren 2015 for the study area. On the forced deportation of groups in the Roman Empire, see also De Blois 2017; Woolf 2017, 38-9.

60 SHA, Tyr. Trig. 6.2: et cum multis auxiliis Postumus iuvaretur Celticis atque Francicis in bellum cum Victorino processit. Cf. De Boone 1954, 36; Willems 1984, 249-50. For the distribution of aurei of Postumus in Germania Magna, cf. Schulte 1983; Degler 2017, map 1.

${ }_{61}$ Pan. Lat. 8 (Nixon and Rodgers 1994), Constantio Caesari 21: tuo, Maximiane Auguste, nutu Nerviorum et Trevirorum arva iacentia postliminio restitutus et receptus in leges Francus excoluit. Cf. De Boone 1954, 57.

62 Pan. Lat. 6 (Nixon and Rodgers 1994), Constantino Augusto 5.3: terram Bataviam, sub ipse quondam alumno suo a diversis Francorum gentibus occupatam omni hoste purgavit. Cf. De Boone 1954, 57-8.

63 Nixon and Rodgers 1994, 224, following La Baume.

64 De Boone 1954, 36, 42, 58; Willems 1984, 249. Identified as Menapian, Carausius cannot easily be named an alumnus of the Franks.
} 
Given the fact that a few decades earlier Postumus had employed troops of Germanic origin and may have offered them settlement, both passages can be interpreted as examples of forced deportation by the imperial authorities of groups living in Batavia. ${ }^{65}$ The Batavian and Cananefatian communities may have made common cause with the Frankish newcomers and consequently received the same punishment from the Roman authorities, namely deportation as laeti to interior Gaul. One may even go a step further and speculate that the praefecti laetorum Batavorum stationed near Arras, Neumagen and Lyon mentioned in the Notitia Dignitatum refer to groups of Batavians and Franks who had been deported as laeti to uninhabited regions of interior Gaul. ${ }^{66}$ Future research will hopefully clarify whether the fourth-century Germanic-type settlements excavated in northern France ${ }^{67}$ can be linked to the historically documented deportations of Germanic groups from Germania inferior. ${ }^{68}$

We conclude that the large number of excavations and the improved dating methods that have become available in recent decades are now allowing us to detect recurrent patterns in site developments. These enable us to add arguments to existing historical debates and to suggest new hypotheses. Even though not all of the above can be proven to the letter, it is clear that one or several catastrophic events in the late third century, in combination with imperial policy and probably environmental problems, led to the dramatic depopulation of the countryside in large parts of Germania inferior.

\section{GERMANIC SETTLEMENT AND DECLINING IMPERIAL POWER}

The historical developments in the fourth and early fifth century in Germania secunda were determined by two key themes. The first is the continuous attempt of the Roman authorities to control the Rhine corridor in order to protect the Gallic hinterland against Germanic raiders and to keep open the strategic routes to Britannia via the Rhine and Meuse. The military history of the late third to fifth century can best be characterised as a period during which times of strength, when Roman military influence was restored in Lower Germany, alternated with times of weakness or even collapse of the limes ${ }^{69}$ As a rule, diminished military attention given to the northern regions led directly to incursions and pillaging by Frankish war bands, while periods of recovery were linked to successful campaigns against Frankish groups by Postumus (c. 260), Aurelian (c. 275), Probus (c. 276-80), Constantius (c. 293-97), Constantine I (c. 310) and Julian II (c. 359). ${ }^{70}$ The notion of the limes as a defensive infrastructure along the Rhine remained alive throughout the fourth century, although little of this was realised in practice. Material dating to the early and mid-fourth century is scarce in, if not virtually absent from, the forts. Most castella were garrisoned incidentally at best. ${ }^{71}$ This period is characterised by Roman field campaigns in times of threat rather than continually manned fortifications. Absolute low points for the limes were Stilicho's withdrawal of regular Roman troops from the

65 Heeren 2015, 290-4. The label 'Batavia' in the written sources may extend outside the area that we know to be the Batavian civitas, to include parts of the sandy soils to the south of it, as well as the Cananefatian civitas (De Bruin 2019, 238).

66 Not. Dign. occ. 42. See also the discussion in Willems 1984, 275.

67 Kasprzyk 2018a, 261-6.

68 Lenz 2005.

69 For an overview of the military history of the Lower Rhine region in the late Roman period, see the excellent thesis of De Boone 1954; cf. also Zöllner 1970, 1-43; Willems 1984, 248-50 (largely relying on De Boone).

70 De Boone 1954; Zöllner 1970.

71 In past decades, incidental finds from military camps were too readily used to suggest continuity of occupation. A dendrochronologically dated fourth-century phase of the Valkenburg castellum was often cited. However, it was discovered recently that the dendrochronological research was faulty and did not support the dating (Rien Polak, pers. comm.). 
Rhine to Italy in 401/02 and the Germanic incursions of 405 or 406 near Mainz. The appearance of the usurper Constantine III (407-11), who is credited by Zosimus as being the last Roman general to restore the Rhine frontier, ${ }^{72}$ represents a short upheaval, after which the limes quickly ceased to be a defensive infrastructure of any real significance.

The second theme, and the most important for this paper, concerns the substantial influx of Germanic groups, or more specifically the groups described as Franks in the written sources, from the period around 400 onwards. Franci is a collective name for a series of smaller tribes in the areas east and north of the Lower Rhine who had long maintained relations with the Roman Empire. Not until the middle of the third century does this name appear in the written accounts. ${ }^{73}$ In the third and fourth centuries Franks were generally described as people living outside the Roman Empire, but in the late fourth and fifth centuries they also inhabited land in Germania secunda. Frankish society underwent a major transformation during the late Roman period, which was closely tied to increasing interaction - both friendly and hostile - with the Roman Empire. Viewed from this perspective, the Franks can be regarded as a product of the late Roman frontier.

Archaeological research over the course of the last two decades has contributed considerably to the discussion about Germanic immigrant groups, most notably the Franks. Historical accounts about Franks settling in the Roman province date to the later third and fourth centuries, but, so far, hardly any tangible remains have been recovered. This also applies to the report that Salian Franks were beaten by Julian II in 359 after they settled in Toxandria. ${ }^{74}$ It is generally understood that they were permitted to settle, but so far there is no archaeological evidence dating to this period. By contrast, there is now ample evidence for immigration dating to the late fourth/early fifth century, visible in house plans, sunken-featured secondary buildings and numerous mobile finds (FIG. 9 and TABLE 1). Remarkably, these settlements have been found in areas that were severely depopulated earlier, mainly in the Meuse valley and the sandy area south and west of the Meuse river stretching as far as the Scheldt valley. In most instances, older settlement locations were used again, after a habitation discontinuity of more than a century.

Migration as an explanation for regional change in the late Roman period merits some elaboration since it has been critically evaluated previously. Archaeologists based narratives of migration on written sources and the etnische Deutung of material culture from burial contexts. ${ }^{75}$ Critical evaluations came from more theoretically oriented scholars, such as Guy Halsall and Frans Theuws, who argued against any ethnic meaning of material culture and explained differences in burial rites in other ways. ${ }^{76}$ Although their criticism is broadly correct, their general conclusion that no Germanic immigration is proven - is not followed by the present authors. Apart from the metal finds, which are accompanied by handmade pottery of Rhine-Weser-Germanic style, the settlement complexes show house plans of a type that was common north of the Rhine and associated with sunken-featured buildings; furthermore, rye is found, a cereal also originating north of the Rhine as a cultivated crop. ${ }^{77}$ Because these various classes of evidence all point to the Germanic origin of the new settlers, we argue that archaeology can prove migration. ${ }^{78}$

Additional archaeological information comes from gold finds, which provide more historical background to this renewed immigration in the (former) Roman province (FIG. 10). ${ }^{79}$ There is a

72 Zos. 6.3.3 reports that Constantine 'let rule a total security along the Rhine, which has been neglected since the age of Julian' (taken from the French edition of Paschoud 1989, 7-8, and translated into English by the present authors).

73 De Boone 1954; Zöllner 1970; Taayke 2003.

74 Amm. Marc. 17.8.

75 For instance, Böhme 1974; 1999; Quast 2009.

76 Halsall 2000; 2007; Theuws 2009.

77 Heeren 2017; Heeren and Roymans 2018.

78 For the broader debate on archaeology and migration, see Burmeister 2000; 2017.

79 Roymans 2017. 


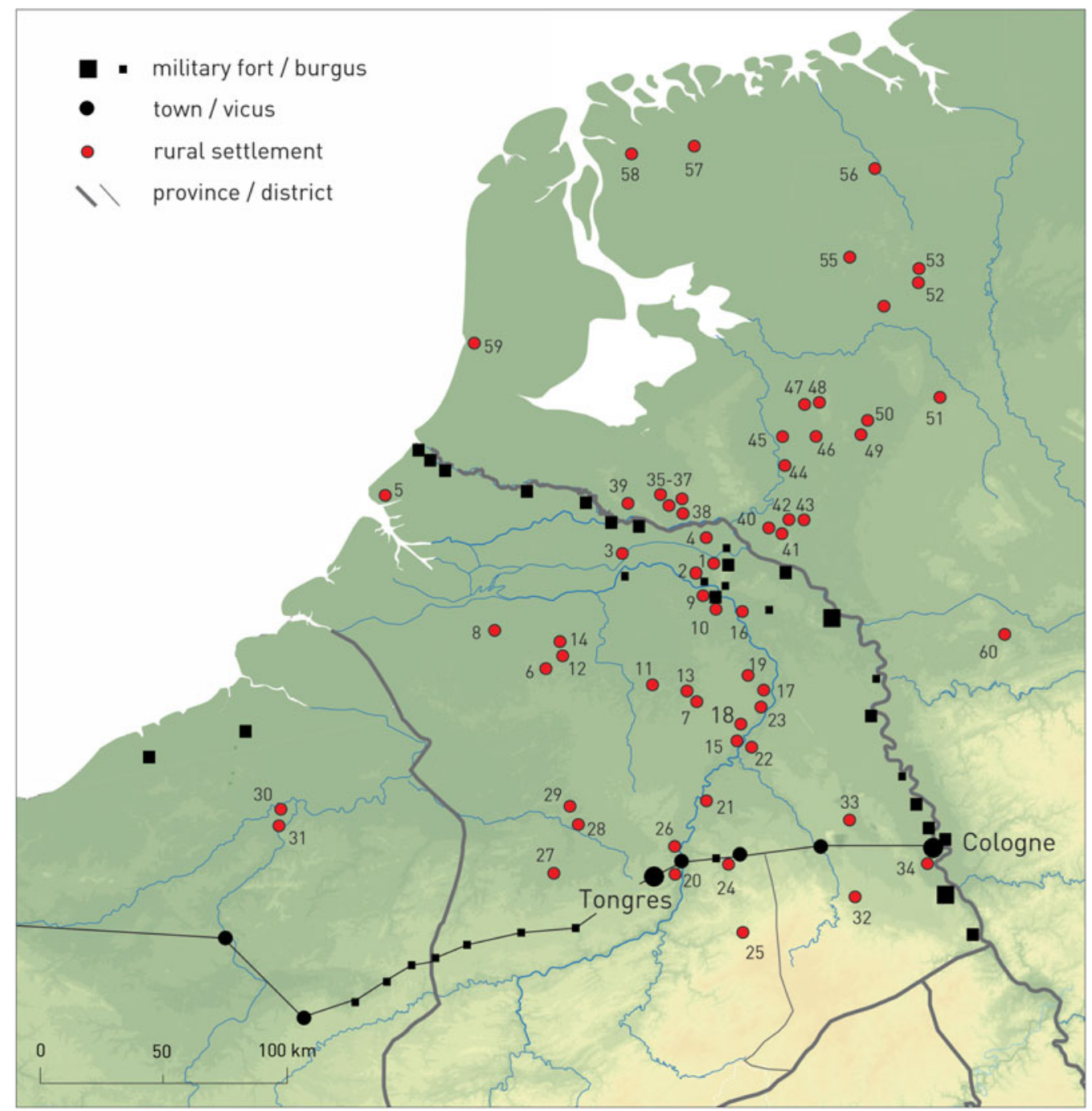

FIG. 9. Distribution of excavated Germanic settlements from the late fourth and early fifth centuries in Germania secunda. The numbering corresponds with the numbering of sites in TABLE 1 .

true gold-hoard horizon in the region and many of the coin-dated hoards have a terminal coin of Honorius (A.D. 395-423) or Constantine III (A.D. 407-11). ${ }^{80}$ Constantine III concluded treaties with Frankish groups and the same is hinted at by the sources about Stilicho, magister militum of Honorius, when he withdrew the regular Roman troops to the south (401-02). In both instances we can surmise that these Franks were allowed to settle in the former province, in return for military service. This settlement took place in uninhabited areas where the troops received the status of foederati, not laeti. The free, federate status of the new settlers is 


\section{TABLE 1. LIST OF EXCAVATED GERMANIC SETTLEMENTS FROM THE LATE FOURTH/EARLY FIFTH} CENTURY IN GERMANIA SECUNDA

(The numbering corresponds with the numbering of sites in FIG. 9 (after Heeren 2017). SFB = sunken featured building. References for the settlements are available in Heeren 2015; 2017; Van Enckevort et al. 2017)

No Site

$1 \quad$ Nijmegen-Sint Canisiussingel

2 Wijchen-Tienakker

3 Tiel-Passewaaij

$4 \quad$ Valburg-Molenzicht

$5 \quad$ Naaldwijk-Hoogwerf

6 Alphen-Kerkakkers

7 Asten-Prins Bernhardstraat

8 Breda West-Steenakker

9 Cuijk-Heeswijkse Kampen

10 Cuijk-De Nielt

11 Geldrop-'t Zand

12 Goirle-Huzarenwei

13 Lierop-Steemertseweg

14 Tilburg-Stappegoor

15 Buggenum-Wijnaerden

16 Gennep-Stamelberg
Grubbenvorst-De Soom

Helden-Schrames

Horst-Hoogveld

Maastricht-Witmakersstraat

Holtum-Noord

Swalmen

Blerick-Heierhoeve

Voerendaal-Ten Hove

Baelen-Nereth

Neerharen-Rekem

Wange-Damekot

Herk-de-Stad, Donk

Meldert-Zelemsebaan

Sint-Martens-Latem

Nazareth-'s-Gravendreef

Froitzheim

Harff

Rodenkirchen

Ede-Veldhuizen

Ede-Op den Berg

Ede-Uitvindersbuurt

Ede-Bennekom

Didam-Aalsbergen/Kollenburg

Didam-Kerkwijk

Wehl-Hessenveld

Wehl-Oldershove

Zutphen-Ooijershoek

Deventer-Colmschate
Leersum-Middenweg
Settlement features and date

Rye

1 SFB; charred; late Roman

Former villa, burgus site 4 th century, settlement ( $8 \mathrm{SFBs}$ ); late

4 th/5th century

Two shorthouses, 1 of Wijster B2 type; late 4 th $/ 5$ th century

2 longhouses (1 possibly Wijster type), 6 wells; late 4 th/5th century

Former vicus, $1 \mathrm{SFB}, 1$ well; late 4 th/5th century

$28 \mathrm{SFBs}, 9$ main houses (no Wijster type); late 4th to early 6th century Yes

$1 \mathrm{SFB}$, coarse pottery; late Roman and/or medieval

6 or 8 SFBs, 2 longhouses of which 1 Wijster type; around A.D. 400

At least 1 SFB; 3rd century or later

2 main buildings (no Wijster type) early 4th century; 6 SFBs late

4th century

13 SFBs, 2 main buildings; late 4th to mid-5th century

Yes

2 SFBs, 4 main buildings ( 3 Wijster type); late 4th/early 5th century Yes

1 SFB; undated; near late Roman pits

2 shorthouses; first half of 5 th century

Several Wijster buildings and SFBs; late 4th/5th century

More than $100 \mathrm{SFBs}$, at least 12 Wijster-like longhouses; late

4 th/ 5 th century

9 SFBs, 2 main buildings; some late 4th/early 5th century, some

medieval

4 SFBs, 6 shorthouses Wijster B2, 1 Wijster longhouse; late 4th/5th century

2 SFBs; apparently 3rd century

1 SFB; mid-5th century

11 longhouses (no Wijster type), $8 \mathrm{SFBs}$; late 4 th/5th century

1 late Roman SFB next to Merovingian cemetery

Around 10 SFBs; late 1st/2nd century settlement, also 4th-century coins

At least 17 SFBs at villa site; 4th to 7 th century

Yes

1 longhouse, 1 shorthouse, 4 possible SFBs; mid- to late 4 th century

At least 25 SFBs, 2 Wijster-like longhouses; late $4^{\text {th }}$ to early 5 th century

7 SFBs at late Roman villa site; 5 th to 6 th century

1 SFB or byre section of longhouse(?); mid- to late 4th century

2 SFBs and unclear main buildings; late 4 th $/ 5$ th century

$1 \mathrm{SFB}$; late 4 th/early 5 th century

Longhouse Wijster A type; late 3rd century(?)

1 SFB within former burgus; c. A.D. 300(?)

2 SFBs on former villa terrain; second half of 4th century

$1 \mathrm{SFB}$ on former villa terrain; 4th century

Yes

180 main houses and large buildings, 4 SFBs, 208 small outbuildings, 67 wells

$80+$ main houses and/or large outbuildings, 65 small outbuildings,

many SFBs

2 longhouses, 2 shorthouses, 2 possible SFBs, 3 to 6 wells

Several longhouses and at least 4 SFBs

Buildings, SFBs; late Roman/early Middle Ages

14 main buildings, more than 30 SFBs, 4 small outbuildings, 26 wells

2 three-aisled main buildings, 4 wells

7 longhouses, some of Wijster type, 11 partial other houses, over 20 SFBs

1 Wijster B2 shorthouse, 2 SFBs; close to Hessenveld

c. 20 SFBs and several Wijster A longhouses

10 or 12 SFBs

Yes 


\section{TABLE 1. CONTINUED}

No Site

46 Bathmen-Bergakker

47 Heeten-Hordelman

48 Heeten-Telgen

49 Markelo-Elsen

50 Wierden-Enter

51 Denekamp-De Borchert

52 Emmen-Noordbarge

53 Emmen-Frieslandweg

54 Coevorden-Diphoorn

55 Wijster

56 Midlaren-De Bloemert

57 Leeuwarden-Oldehoofsterkerkhof

58 Wijnaldum-Tjitsma

59 Castricum-Oosterbuurt

60 Castrop-Rauxel, Ickern
Settlement features and date

Some SFBs; one with a confirmed 4th-century date

39 SFBs

14 SFBs, longhouses

$1 \mathrm{SFB}$, pits, a well (trial trench)

3 SFBs, longhouse

11 SFBs, various longhouses

c. $35 \mathrm{SFBs}$, some longhouses

8 SFBs, longhouses

1 SFB, longhouses

c. 85 SFBs, many Wijster longhouses and shorthouses

27 SFBs, various types of longhouses

Several Wijster-type longhouses

Several Wijster-type longhouses

Several Wijster-type longhouses

2 Wijster-type longhouses

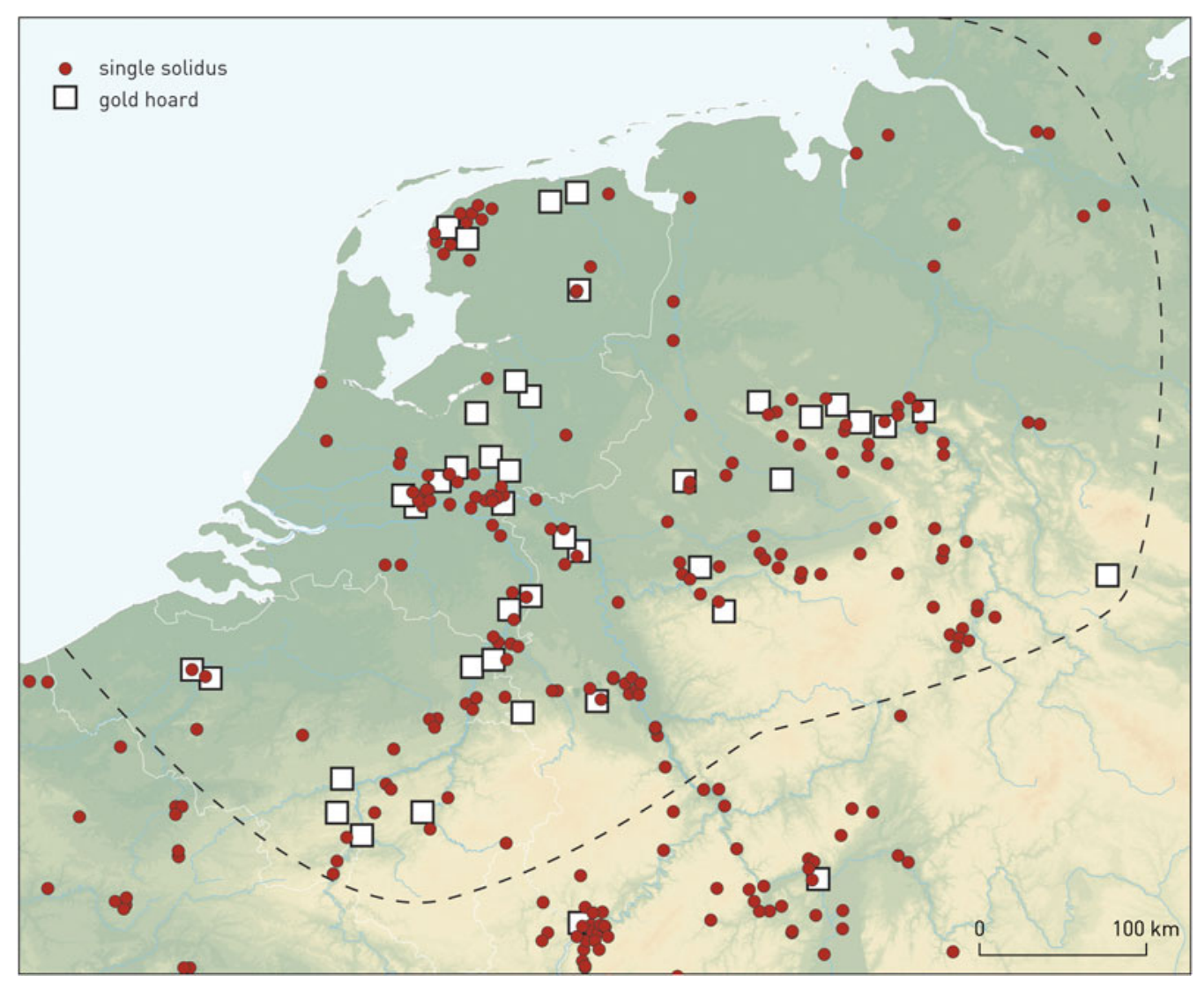

FIG. 10. Distribution of late Roman solidi (A.D. 364-455) in the Lower Rhine frontier zone (after Roymans 2017, fig. 1, with additions). 
supported by the study of the extensive gold circulation and deposition in this period (FIG. 10). The large-scale payments of Roman gold in the form of solidi and ornaments to Frankish groups illustrate the shifting balance of power on the late Roman frontier.

We conclude that there was a partial repopulation of the countryside around the turn of the fourth to the fifth century. This model of substantial Germanic immigration to the Roman province is particularly valid for former substantially depopulated areas, but this may also be due to the greater archaeological visibility of immigration in those areas. The motor behind the gold payments and land allotments to Germanic groups was the control over the war bands recruited from these rural groups. What is new in this migration discussion is the combined approach analysing historical sources, house forms, food remains, jewellery and pottery. The next step currently underway is to combine these data with the isotopic analysis of animal teeth (because livestock may have been brought on the hoof in the case of first-generation settlers) and the analysis of burial customs in relation to the isotopic signature of human remains (both inhumed and cremated).

\section{CONCLUSIONS AND DISCUSSION}

The case study of Germania inferior presented above teaches us that rural populations were generally integrated more closely into Roman imperial structures than is often assumed. Geographically, they may have been far removed from the urban or military centres, but imperial power networks extended into the furthest corners of every civitas. In Lower Germany rural groups had to contend not only with taxation and recruitment systems, but, in situations of crisis, also with extreme mass violence, land expropriation and forced deportations. Central to this perspective is the understanding of power relations, including their economic and religious dimensions. Archaeology has the potential to explore further and operationalise this theme in regional research programmes.

Certain issues keep recurring in the analysis outlined above. The first is human mobility. In the first two centuries A.D. this was primarily individual mobility, linked to service in the Roman army. In other periods it mainly involved group migrations associated with demographic rearrangements of rural populations in a region. A second recurring theme is the intense connectivity between rural communities and the Roman military domain. Certainly in a heavily militarised frontier province, rural developments cannot be understood without considering the multifaceted networks with the military community. A third recurring theme is the phenomenon of the appearing and disappearing ethnic groups of the Roman frontier zone. The written sources suggest that most frontier tribes were to some extent new political creations; this is supported by archaeological research showing that tribal units often lacked a homogenous material footprint in the spheres of pottery style, house architecture and ornaments.

By far the most dominant narrative in Roman rural archaeology is that of the progressive romanisation of groups, thereby focusing on the rise of villa landscapes, a monetary economy, a market-oriented production and new styles of consumption. From the perspective employed in this study we present an alternative series of topics embedded in a different narrative, which are only marginally discussed in most archaeological syntheses, but which should not be absent from a balanced approach to developments in the Roman countryside. One might even go a step further and state that the developments discussed in this paper must have been experienced as dramatic episodes by the rural communities themselves.

The above insights obtained for the Lower Germanic region also lend themselves to comparison with developments in other provinces. The recent synthesis available for Roman Britain shows important differences on some main points. Alexander Smith and Michael Fulford conclude 
that the Roman conquest had no significant impact on existing settlement patterns in Britannia; the general pattern was one of continuity of rural settlement from the late Iron Age to the later second century A.D. ${ }^{81}$ Also absent from Britannia are indications of a substantial influx of external groups in the early post-conquest period, and ethnic recruitment there certainly did not reach the high levels attested for Germania inferior. Finally, the process of settlement abandonment and depopulation of the countryside in the late Roman period followed a more gradual pattern without a dramatic low point in the late third century. ${ }^{82}$ The recent synthesis presented by Reddé and colleagues for interior Gaul and more specifically the province of Gallia Belgica also shows differences from the patterning sketched for Germania inferior. In many regions there is evidence for a substantial population decline in the La Tène $\mathrm{D}$ period, but here the Roman conquest seems to have played a secondary role at most, since the trend had already started in the late second century B.C. ${ }^{83}$ A gradual increase in the population is observed from the Augustan period onward, but the immigration of tribal groups did not play any role there. ${ }^{84}$ The level of ethnic recruitment in interior Gaul is not discussed, but according to the historical sources it must have been of limited importance (see FIG. 6). As in Britannia, the rural settlement pattern seems to have remained largely intact well into the fourth century. ${ }^{85}$ There is some evidence for the appearance of Germanic-type settlements in the Seine valley in the fourth century, but it is too early to draw any conclusions about the relative extent of this phenomenon.

This comparison along main lines with the evidence from Britannia and Gallia Belgica teaches us that the developments sketched for Germania inferior are largely specific to that area and cannot simply be extrapolated to other provinces. Each province has its own story to tell, which for Germania inferior is determined above all by the continuous and multifaceted interaction with the immense territory and many peoples of Germania magna. In all provinces, however, rural communities were deeply embedded in the power structures of the Roman Empire. Power-related themes affecting rural communities - such as warfare, mass violence, deportation and economic exploitation and repression - are increasingly marginalised in current research, which often focuses on the 'soft', cultural dimensions of the transformation of the rural world.

Finally, the analysis above shows us that written sources can generate interesting hypotheses for archaeological research and that, vice versa, archaeological insights may lead to different interpretations of written sources or draw our attention to major biases in the historical record. There is an abundance of themes for combined historical-archaeological research, and the constant increase in the quantity and quality of archaeological data allows us to ask more complex questions. In contrast to the situation a few generations ago, archaeology no longer participates in this debate as an historical sub-discipline, but as an autonomous discipline which has its own methodologies and generates its own empirical data. We can look forward to a phase of renewed interdisciplinary cooperation.

\section{ACKNOWLEDGEMENTS}

The authors wish to thank Andrew Lawrence (University of Bern) and the anonymous reviewer of Britannia for their comments on an earlier draft of this paper, and Bert Brouwenstijn for the cartography and illustrations. The English was checked by Annette Visser (New Zealand). This study is part of the research output of the projects Portable Antiquities of the Netherlands and Tiel-Medel as a Key Site for

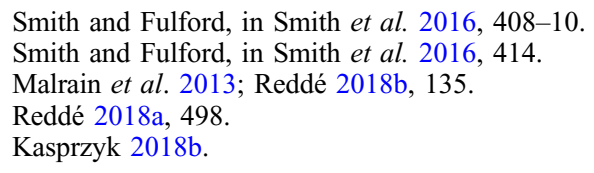


Innovative Research Towards Migration and Ethnogenesis in the Roman Frontier. Both projects are funded by the Netherlands Organisation for Scientific Research and are run by the Archaeological Department of Vrije Universiteit Amsterdam.

Department of Archaeology, Classics and Ancient Studies, Vrije Universiteit Amsterdam (N.R., T.D. and S.H.)

n.g.a.m.roymans@vu.nl

a.m.j.derks@vu.nl

s.heeren@vu.nl

\section{BIBLIOGRAPHY}

Alföldy, G. 1968: Die Hilfstruppen in der römischen Provinz Germania inferior, Epigraphische Studien 6, Düsseldorf

Allen, M., Lodwick, L., Brindle, T., Fulford, M., and Smith, A. (eds) 2017: The Rural Economy of Roman Britain, Britannia Monograph 30, London

Andrews, C. 2013: 'Are Roman seal-boxes evidence for literacy?', Journal of Roman Archaeology 26, 423-38

Andrikopoulou-Strack, J.-N., Enzenberger, P., Frank, K., Keller, C., and Klän, N. (eds) 1999: 'Eine frührömische Siedlung in Jüchen-Neuholz: Überlegungen zur Siedlungskontinuität in der Lößbörde', Bonner Jahrbücher 199, 141-80

Bechert, T. 1982: Römisches Germanien, Munich

Bloemers, J.H.F. 1978: Rijswijk (Z.H.), 'De Bult': eine Siedlung der Cananefaten I-III, Amersfoort

Böhme, H.W. 1974: Germanische Grabfunde des 4. und 5. Jahrhunderts zwischen unterer Elbe und Loire: Studien zur Chronologie und Bevölkerungsgeschichte, Münchner Beiträge zur Vor- und Frühgeschichte 19, Munich

Böhme, H.W. 1999: 'Sächsische Söldner im römischen Heer: das Land zwischen Ems und Niederelbe während das 4. und 5. Jahrhundert', in F. Both and H. Aouni (eds), Über allen Fronten: Nordwestdeutschland zwischen Augustus und Karl dem Grossen, Archäologische Mitteilungen aus Nordwestdeutschland Beiheft 26, Oldenburg, 49-73

Bowman, A.K., and Thomas, J.D. 1994-2003: The Vindolanda Writing Tablets: Tabulae Vindolandenses 2-3, London

Breeze, D. 2018: 'The value of studying Roman frontiers', Theoretical Roman Archaeology Journal 1.1, https://doi.org/10.16995/traj.212

Bridger, C. 2003: 'Das spätantike Xanten: eine Bestandsaufnahme', in T. Grünewald and S. Seibel (eds), Kontinuität und Diskontinuität: Germania inferior am Beginn und am Ende der römischen Herrschaft, Berlin and New York, 12-36

Brüggler, M., Jeneson, K., Gerlach, R., Meurers-Balke, J., Zerl, T., and Herchenbach, M. (eds) 2017: 'The Roman Rhineland: farming and consumption in different landscapes', in M. Reddé (ed.), Gallia Rustica 1: les campagnes du nord-est de la Gaule, de la fin de l'âge du Fer à l'Antiquité tardive, Ausonius Éditions Mémoires 49, Bordeaux, 19-96

Burmeister, S. 2000: 'Archaeology and migration: approaches to an archaeological proof of migration', Current Anthropology 41.4, 539-67

Burmeister, S. 2017: 'One step beyond: Migration als kulturelle Praxis', in A. Dietz, A. Hidding and J.D. Preisigke (eds), Migration and Change: Causes and Consequences of Mobility in the Ancient World, Distant Worlds Journal 3, Munich, 3-18

Clotuche, R., Derreumaux, M., Pigière, F., Jouanin, G., Preiss, S., and Yvinec, J.-V. (eds) 2017: 'Les campagnes du territoire nervien: approches croisées', in M. Reddé (ed.), Gallia Rustica 1: les campagnes du nord-est de la Gaule, de la fin de l'âge du Fer à l'Antiquité tardive, Ausonius Éditions Mémoires 49, Bordeaux, 179-210

De Blois, L. 2017: 'Invasions, deportations, and repopulation: mobility and migration in Thrace, Moesia Inferior, and Dacia in the third quarter of the third century AD', in E. Lo Cascio and L.E. Tacoma (eds), The Impact of Mobility and Migration in the Roman Empire, Impact of Empire 22, Leiden and Boston, 42-54

De Boone, W.J. 1954: De Franken van hun eerste optreden tot de dood van Childerik, Groningen 
De Bruin, J. 2019: Border Communities at the Edge of the Roman Empire: Processes of Change in the Civitas Cananefatium, Amsterdam Archaeological Studies 28, Amsterdam

De Jonge, W., Bazelmans, J., and de Jager, D. (eds) 2006: Forum Hadriani: van Romeinse stad tot monument, Utrecht

Degler, A. 2017: 'Aureus of Postumus with the owner's graffito (Gounthiou)', Proceedings XV: International Numismatic Congress Taormina 2015, Taormina, 723-6

Derks, T. 2009: 'Ethnic identity in the Roman frontier: the epigraphy of Batavi and other Lower Rhine tribes', in T. Derks and N. Roymans (eds), Ethnic Constructs in Antiquity: The Role of Power and Tradition, Amsterdam Archaeological Studies 13, Amsterdam, 239-82

Derks, T., and Roymans, N. 2002: 'Seal-boxes and the spread of Latin literacy in the Rhine delta', in A.E. Cooley (ed.), Becoming Roman, Writing Latin? Literacy and Epigraphy in the Roman West, Journal of Roman Archaeology Supplement 48, Porthsmouth, RI, 87-134

Drinkwater, J. 2008: 'Maximinus to Diocletian and the "crisis", in A.P. Bowman, P. Garnsey and A. Cameron (eds), The Cambridge Ancient History 12: The Crisis of Empire AD 193-337, Cambridge, 28-66

Eck, W. 2004: Köln in römischer Zeit: Geschichte einer Stadt im Rahmen des Imperium Romanum, Cologne

Eck, W. 2008: 'Die Gründung der Colonia Ulpia Traiana in ihrem politische Kontext', in M. Müller, H.J. Schalles and N. Zieling (eds), Colonia Ulpia Traiana: Xanten und sein Umland in römischer Zeit, Mainz, 243-55

Eckardt, H., and Müldner, G. 2016: 'Mobility, migration, and diaspora in Roman Britain', in M. Millett, L. Revell and A. Moore (eds), The Oxford Handbook of Roman Britain, Oxford, 202-23

Erdrich, M. 1998: 'Terra Nigra-Fussschalen wie Chenet 342 oder Gellep 273: eine salisch-fränkische Keramikgattung', Germania 76-2, 875-84

Frank, K. 2018: 'Mehrum: neues zu einem alten Grabfund', in M. Aufleger and P. Tutlies (eds), Das Ganze ist mehr als die Summe seiner Teile: Festschrift für Jürgen Kunow, Bonn, 465-76

Gaitzsch, W. 2011: 'Roman villa landscapes of the lignite mining areas in the hinterland of Cologne', in N. Roymans and T. Derks (eds), Villa Landscapes in the Roman North: Economy, Culture and Lifestyles, Amsterdam Archaeological Studies 17, Amsterdam, 285-300

Galsterer, H. 1990: 'Von den Eburonen zu den Agrippinensern', Kölner Jahrbuch 23, 117-26

Gardner, A. 2013: 'Thinking about Roman imperialism: postcolonialism, globalisation and beyond?', Britannia 44, 1-25

Gechter, M., and Kunow, J. 1986: 'Zur ländlichen Besiedlung des Rheinlandes in römischer Zeit', Bonner Jahrbücher 186, 377-96

Gouw-Bouman, M.T.I.J., van Asch, N., Engels, S., and Hoek, W.Z. 2019: 'Late Holocene ecological shifts and chironomid-inferred summer temperature changes reconstructed from Lake Uddelermeer, the Netherlands', Palaeogeography, Palaeoclimatology, Palaeoecology 535, 109366, https://doi.org/10. 1016/j.palaeo.2019.109366

Groenman-Van Waateringe, W. 1983: 'The disastrous effect of the Roman occupation', in R. Brandt and J. Slofstra (eds), Roman and Native in the Low Countries: Spheres of Interaction, BAR International Series 184, Oxford, 147-57

Haas, J. 2006: Die Umweltkrise des 3. Jahrhunderts n. Chr. im Nordwesten des Imperium Romanum: interdisziplinäre Studien zu einem Aspekt der allgemeinen Reichskrise im Bereich der beiden Germaniae sowie der Belgica und der Raetia, Geographica Historica 22, Stuttgart

Halsall, G. 2000: 'Archaeology and the late Roman frontier in northern Gaul: the so-called "Föderatengräber" reconsidered', in W. Pohl and H. Reimitz (eds), Grenze und Differenz im frühen Mittelalter, Forschungen zur Geschichte des Mittelalters 1/Österreichische Akademie der Wissenschaften, Philosophisch-Historische Klasse Denkschriften 287, Vienna, 167-80

Halsall, G. 2007: Barbarian Migrations and the Roman West 376-568 (2nd edn), Cambridge

Haselgrove, C. 1984: 'Warfare and its aftermath as reflected in the precious metal coinage of Belgic Gaul', Oxford Journal of Archaeology 3.1, 81-105

Haselgrove, C. 2019: 'The Gallic War in the chronology of Iron Age coinage', in A. Fitzpatrick and C. Haselgrove (eds), Julius Caesar's Battle for Gaul: New Archaeological Perspectives, Oxford and Philadelphia, 241-66 
Heeren, S. 2009: Romanisering van rurale gemeenschappen in de civitas Batavorum: de casus Tiel-Passewaaij, Nederlandse Archeologische Rapporten 36, Amersfoort

Heeren, S. 2015: 'The depopulation of the Lower Rhine region in the third century: an archaeological perspective', in N. Roymans, T. Derks and H.A. Hiddink (eds), The Roman Villa of Hoogeloon and the Archaeology of the Periphery, Amsterdam Archaeological Studies 22, Amsterdam, 271-94

Heeren, S. 2017: 'From Germania Inferior to Germania secunda and beyond: a case study of migration, transformation and decline', in N. Roymans, S. Heeren and W. De Clercq (eds), Social Dynamics in the Northwest Frontiers of the Late Roman Empire: Beyond Decline or Transformation, Amsterdam Archaeological Studies 26, Amsterdam, 149-78

Heeren, S., and Roymans, N. 2018: 'Contextualising ethnicity and the rhetoric of burial rites in late antique northern Gaul: the evidence from settlements and precious metal circulation', in M. Kars, R. van Oosten, M.A. Roxburgh and A. Verhoeven (eds), Rural Riches and Royal Rags? Studies on Medieval and Modern Archaeology, Presented to Frans Theuws, Zwolle, 8-14

Heimberg, U. 2002-03: 'Römische Villen an Rhein und Maas', Bonner Jahrbücher 202-3, 57-148

Heinrichs, J. 2001: 'Römische Perfidie und germanischer Edelmut? Zur Umsiedlung protocugernischer Gruppen in den Raum Xanten 8 v.Chr.', in T. Grünewald (ed.), Germania inferior: Besiedlung, Gesellschaft und Wirtschaft an der Grenze der römisch-germanischen Welt, Berlin and New York, 54-92

Hingley, R. 2005: Globalizing Roman Culture: Unity, Diversity and Empire, London

Hornung, S. 2016: Siedlung und Bevölkerung in Ostgallien zwischen Gallischem Krieg und der Festigung der römischen Herrschaft, Römisch-Germanische Forschungen 73, Darmstadt and Mainz

Huskinson, J. (ed.) 2000: Experiencing Rome: Culture, Identity and Power in the Roman Empire, London

Kalis, A.J., Karg, S., Meurers-Balke, J., and Teunissen-van Oorschot, H. 2008: 'Mensch und Vegetation am unteren Niederrhein während der Eisen- und Römerzeit', in M. Müller, H.J. Schalles and N. Zieling (eds), Colonia Ulpia Traiana: Xanten und sein Umland in römischer Zeit, Mainz, 31-48

Kalis, A.J., and Meurers-Balke, J. 2007: 'Landnutzung im Niederrheingebiet zwischen Krieg und Frieden', in M. Hegewisch (ed.), Krieg und Friede: Kelten Römer Germanen, Bonn, 144-53

Kasprzyk, M. 2018a: 'L'équipement et les formes des établissements ruraux du Bas-Empire (milieu du IIIe milieu du Ve siècle p.C.) dans l'est du diocèse des Gaules', in M. Reddé (ed.), Gallia Rustica 2: les campagnes du nord-est de la Gaule, de la fin de l'âge du Fer à l'Antiquité tardive, Bordeaux, 235-305

Kasprzyk, M. 2018b: 'Les mutations de l'Antiquité tardive dans l'est du diocèse des Gaules', in M. Reddé (ed.), Gallia Rustica 2: les campagnes du nord-est de la Gaule, de la fin de l'âge du Fer à l'Antiquité tardive, Bordeaux, 611-35

Krebs, C.B. 2006: “'Imaginary geography” in Caesar's Bellum Gallicum', American Journal of Philology $127.1,111-36$

Krebs, C.B. 2011: 'Borealism: Caesar, Seneca, Tacitus and the Roman discourse about the Germanic north', in E. Gruen (ed.), Cultural Identity in the Ancient Mediterranean: Issues and Debates, Los Angeles, 202-21

Krebs, C.B. 2018: 'The world's measure: Caesar's geographies of Gallia and Britannia in their contexts and as evidence of his world map', American Journal of Philology 139, 93-122

Lenz, K.H. 1999: Siedlungen der römischen Kaiserzeit auf den Aldenhovener Platte, Rheinische Ausgrabungen 45, Cologne and Bonn

Lenz, K.H. 2005: 'Germanische Siedlungen des 3. bis 5. Jahrhunderts n.Chr. in Gallien: schriftliche Überlieferung and archäologische Befunde', Berichte der Römisch-Germanischen Kommission 86, 349444

Lenz, K.H. 2006: 'Veteranen der römischen Armee im Siedlungsbild einer früh- und mittelkaiserzeitlichen Koloniestadt und deren Hinterland: das Beispiel der Colonia Claudia Ara Agrippinensium (Köln)', Germania 84, 61-91

Malrain, F., Blancquart, G., and Lorho, T. 2013: L'habitat rural du Second Âge du Fer: rythmes de création et d'abandon au nord de la Loire, Paris

Mattingly, D. 2006: An Imperial Possession: Britain in the Roman Empire 54 BC-AD 409, London

Mattingly, D.J. 2011: Imperialism, Power and Identity: Experiencing the Roman Empire, Princeton and Oxford

McCormick, M., Büntgen, U., Cane, M., Cook, E.R., Harper, P., Huybers, P., Litt, T., Manning, S.W., Mayewski, P.A., More, A., Nicolussi, K., and Tegel, W. 2012: 'Climate change during and after the 
Roman Empire: reconstructing the past from scientific and historical evidence', Journal of Interdisciplinary History 43.2, 169-220

Nash, D. 1987: 'Imperial expansion under the Roman Republic', in M. Rowlands, M. Trolle Larsen and K. Kristiansen (eds), Centre and Periphery in the Ancient World, Cambridge, 87-103

Nicolay, J. 2007: Armed Batavians: Use and Significance of Weaponry and Horse Gear from Non-Military Contexts in the Rhine Delta (50 BC-AD 450), Amsterdam Archaeological Studies 11, Amsterdam

Nixon, C.E.V., and Rodgers, B.S. 1994: In Praise of Later Roman Emperors: The Panegyrici Latini: Introduction, Translation and Historical Commentary, Transformation of the Classical Heritage 21, Berkeley

Otten, T., and Ristow, S. 2008: 'Xanten in der Spätantike', in M. Müller, H.J. Schalles and N. Zieling (eds), Colonia Ulpia Traiana: Xanten und sein Umland in römischer Zeit, Mainz, 549-82

Päffgen, B. 2012: 'Köln und sein Umland zur Zeit der Soldatenkaiser (235-285 n.Chr.), besonders im Hinblick auf das Gallische Sonderreich', in T. Fischer (ed.), Die Krise des 3. Jahrhunderts n.Chr. und das Gallische Sonderreich: Akten des interdisziplinären Kolloquiums Xanten 2009, Wiesbaden, 97-150

Paschoud, F. 1989: Zosime: Histoire nouvelle III-2 (livre VI et index), Paris

Quast, D. 2009: Foreigners in Early Medieval Europe: Thirteen International Studies on Early Medieval Mobility, Monographien des Römisch-Germanischen Zentralmuseums 78, Mainz

Raepsaet, G. 2013: 'L'ethnogenèse de la civitas Tungrorum et la formation de la province de Germanie', L'Antiquité classique 82, 11-148

Raepsaet-Charlier, M.-T. 2002-03: 'Vielfalt und kultureller Reichtum in den civitates Niedergermaniens', Bonner Jahrbücher 172, 35-56

Reddé, M. (ed.) 2017: Gallia Rustica 1: les campagnes du nord-est de la Gaule, de la fin de l'âge du Fer à l'Antiquité tardive, Bordeaux

Reddé, M. (ed.) 2018a: Gallia Rustica 2: les campagnes du nord-est de la Gaule, de la fin de l'âge du Fer à l'Antiquité tardive, Bordeaux

Reddé, M. 2018b: 'The impact of the German frontier on the economic development of the countryside of Roman Gaul', Journal of Roman Archaeology 31, 131-60

Riechelmann, D.F.C., and Gouw-Bouman, M.T.I.J. 2019: 'A review of climate reconstructions from terrestrial climate archives covering the first millennium AD in northwestern Europe', Quaternary Research 91.1, 111-31

Riggsby, A. 2006: Caesar in Gaul and Rome: War in Words, Austin

Roymans, N. 2004: Ethnic Identity and Imperial Power: The Batavians in the Early Roman Empire, Amsterdam Archaeological Studies 10, Amsterdam

Roymans, N. 2009: 'Hercules and the construction of a Batavian identity in the context of the Roman empire', in T. Derks and N. Roymans (eds), Ethnic Constructs in Antiquity: The Role of Power and Tradition, Amsterdam Archaeological Studies 13, Amsterdam, 219-38

Roymans, N. 2011: 'Ethnic recruitment, returning veterans and the diffusion of Roman culture among rural populations in the Rhineland frontier zone', in N. Roymans and T. Derks (eds), Villa Landscapes in the Roman North: Economy, Culture and Lifestyles, Amsterdam Archaeological Studies 17, Amsterdam, $139-60$

Roymans, N. 2017: 'Gold, Germanic foederati and the end of imperial power in the late Roman north', in N. Roymans, S. Heeren and W. De Clercq (eds), Social Dynamics in the Northwest Frontiers of the Late Roman Empire: Beyond Decline or Transformation, Amsterdam Archaeological Studies 26, Amsterdam, 57-80

Roymans, N. 2018: 'A Roman massacre in the far north: Caesar's annihilation of the Tencteri and Usipetes in the Dutch river area', in M. Fernández-Götz and N. Roymans (eds), Conflict Archaeology: Materialities of Collective Violence in Late Prehistoric and Early Historic Europe, 167-81

Roymans, N. 2019: 'Conquest, mass violence and ethnic stereotyping: investigating Caesar's actions in the Germanic frontier zone', Journal of Roman Archaeology 32, 439-58

Roymans, N., and Derks, T. (eds) 2011: Villa Landscapes in the Roman North: Economy, Culture and Lifestyles, Amsterdam Archaeological Studies 17, Amsterdam

Roymans, N., and Derks, T. 2015: 'Towards a narrative of the social history of the Hoogeloon villa settlement', in N. Roymans, T. Derks and H.A. Hiddink (eds), The Roman Villa of Hoogeloon and the Archaeology of the Periphery, Amsterdam Archaeological Studies 22, Amsterdam, 295-306 
Roymans N., Derks, T., and Hiddink, H.A. (eds) 2015: The Roman Villa of Hoogeloon and the Archaeology of the Periphery, Amsterdam Archaeological Studies 22, Amsterdam

Roymans, N., Heeren, S., and De Clercq, W. (eds) 2017: Social Dynamics in the Northwest Frontiers of the Late Roman Empire: Beyond Decline or Transformation, Amsterdam Archaeological Studies 26, Amsterdam

Roymans, N., and Scheers, S. 2012: 'Eight gold hoards from the Low Countries: a synthesis', in N. Roymans, G. Creemers and S. Scheers (eds), Late Iron Age Gold Hoards from the Low Countries and the Caesarian Conquest of Northern Gaul, Amsterdam Archaeological Studies 18, Amsterdam, 1-46

Rüger, C. 1968: Germania inferior: Untersuchungen zur Territorial- und Verwaltungsgeschichte Niedergermaniens in der Prinzipatszeit, Beihefte Bonner Jahrbücher 30, Cologne and Graz

Schadee, H. 2008: 'Caesar's construction of northern Europe: inquiry, contact and corruption in De Bello Gallico', The Classical Quarterly 58, 158-80

Scharff, R. 2005: Der Dux Mogontiacensis und die Notitia Dignitatum, Ergänzungsbände zum Reallexikon der Germanische Altertumskunde 50, Berlin and New York

Schulte, B. 1983: Die Goldprägung der gallischen Kaiser von Postumus bis Tetricus, Aarau

Seeck, O. 1876 (1962): Notitia Dignitatum: accedunt Notitia urbis Constantinopolitanae et laterculi prouinciarum, Frankfurt

Slofstra, J. 2002: 'Batavians and Romans on the Lower Rhine: the romanisation of a frontier area', Archaeological Dialogues 9, 16-38

Smith, A., Allen, M., Brindle, T., and Fulford, M. 2016: The Rural Settlement of Roman Britain, Britannia Monograph 29, London

Smith, A., Allen, M., Brindle, T., Fulford, M., Lodwick, L., and Rohnbogner, A. 2018: Life and Death in the Countryside of Roman Britain, Britannia Monograph 31, London

Taayke, E. 2003: 'Wir nennen sie Franken und sie lebten nördlich des Rheins, 2.-5. Jh', in E. Taayke, J.H. Looijenga, O.H. Harsema and H.R. Reinders (eds), Essays on the Early Franks, Groningen Archaeological Studies 1, Groningen, 1-23

Taayke, E., Peen, C., Van der Harst-Van Domburg, M., and Vos, W. 2012: Ede vol erven: Germaanse bewoning op de rand van een wereldrijk (500 voor Chr. tot 500 na Chr.), Leiden

Theuws, F. 2009: 'Grave goods, ethnicity, and the rhetoric of burial rites in late antique northern Gaul', in T. Derks and N. Roymans (eds), Ethnic Constructs in Antiquity: The Role of Power and Tradition, Amsterdam Archaeological Studies 13, Amsterdam, 283-319

Todd, M. 2008: 'The Germanic people and Germanic society' in A.P. Bowman, P. Garnsey and A. Cameron (eds), The Cambridge Ancient History 12: The Crisis of Empire AD 193-337, Cambridge, 440-60

Van Driel-Murray, C. 2003: 'Ethnic soldiers: the experience of the Lower Rhine tribes', in T. Grünewald and S. Seibel (eds), Kontinuität und Diskontinuität: Germania inferior am Beginn und am Ende der römischen Herrschaft, Berlin and New York, 200-17

Van Enckevort, H., Hendriks, J., and Nicasie, M. 2017: Nieuw licht op donkere eeuwen: de overgang van de laat-Romeinse tijd naar de vroege middeleeuwen in Zuid-Nederland, Nederlandse Archeologische Rapporten 58, Amersfoort

Van Enckevort, H., and Thijssen, J.R.A.M. 2014: 'Het Valkhof en omgeving tot aan het einde van de Romeinse tijd', in H. Peterse, D. Verhoeven, R. Camps, R. Klein, B. Kruijsen, J. Kuys, M. Nicasie and M. Smit (eds), Het Valkhof 200 jaar geschiedenis, Nijmegen, 23-42

Van Es, W.A. 1967: Wijster: A Native Village beyond the Imperial Frontier, AD 150-425, Groningen

Vanderhoeven, A. 2017: 'The late Roman town of Tongeren', in N. Roymans, S. Heeren and W. De Clercq (eds), Social Dynamics in the Northwest Frontiers of the Late Roman Empire: Beyond Decline or Transformation, Amsterdam Archaeological Studies 26, Amsterdam, 127-48

Verhagen, J., and Heeren, S. 2016: 'Castra Herculis: de naam van de Romeinse militaire versterking in Nijmegen herontdekt', Westerheem 65, 239-49

Vos, W.K. 2009: Bataafs platteland: het Romeinse nederzettingslandschap in het Nederlandse Kromme-Rijngebied, Nederlandse Archeologische Rapporten 35, Amersfoort

Webster, J., and Cooper, N.J. (eds) 1996: Roman Imperialism, Post-Colonial Perspectives: Proceedings of a Symposium Held at Leicester University in November 1994, Leicester archaeology Monograph 3, Leicester Whittaker, C.R. 1994: Frontiers of the Roman Empire: A Social and Economic Study, Baltimore and London 
Whittaker, C.R. 2009: 'Ethnic discourses on the frontiers of Roman Africa', in T. Derks and N. Roymans (eds), Ethnic Constructs in Antiquity: The Role of Power and Tradition, Amsterdam Archaeological Studies 13, Amsterdam, 189-206

Willems, W.J.H. 1984: 'Romans and Batavians: a regional study in the Dutch eastern river area II', Berichten van de Rijksdienst voor het Oudheidkundig Bodemonderzoek 34, 39-331

Willems, W.J.H., van Enckevort, H., and Thijssen J.R.A.M. 2009: 'From Batavians to Franks: changes in late antiquity', in W.J.H. Willems and H. van Enckevort (eds), VLPIA NOVIOMAGVS Roman Nijmegen: The Batavian Capital at the Imperial Frontier, Journal of Roman Archaeology Supplement 73, Portsmouth, RI, 95-105

Wolters, R. 2001: 'Germanische Mobilität und römische Ansiedlungspolitik: Voraussetzungen und Strukturen germanischer Siedlungsbewegungen im römischen Grenzland', in T. Grünewald (ed.), Germania inferior: Besiedlung, Gesellschaft und Wirtschaft an der Grenze der römisch-germanischen Welt, Berlin and New York, 146-68

Woolf, G. 2017: 'Moving peoples in the early Roman Empire', in E. Lo Cascio and L.E. Tacoma (eds), The Impact of Mobility and Migration in the Roman Empire, Impact of Empire 22, Leiden and Boston, 25-41

Zöllner, E. 1970: Geschichte der Franken bis zur Mitte des sechsten Jahrhundert, Munich 